\title{
A ciklin $\mathbf{C}$ promóter müködésének jellegzetességei emlősökben
}

Ph. D. értekezés

Dr. Blazsó Péter Gábor

Témavezető: Dr. Katona Róbert

Biológia Doktori Iskola

MTA SZBK Genetikai Intézet

SZTE TTIK

2011.

Szeged 


\section{Tartalomjegyzék}

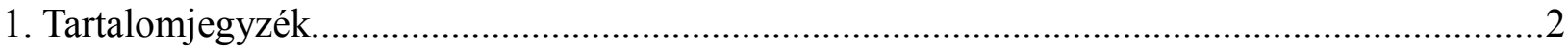

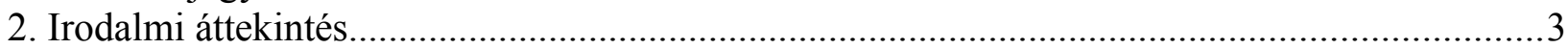

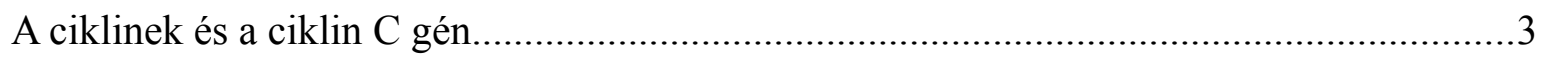

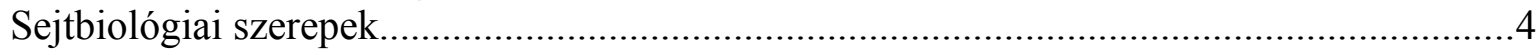

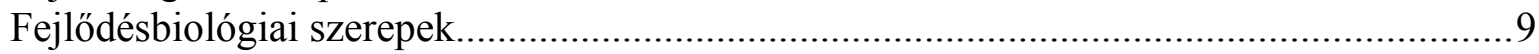

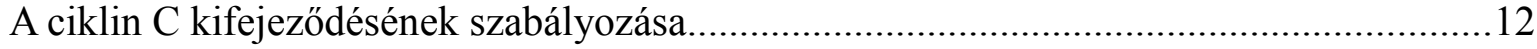

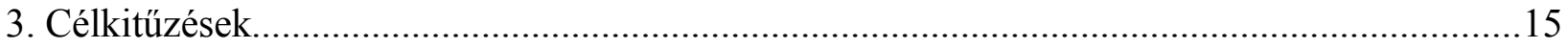

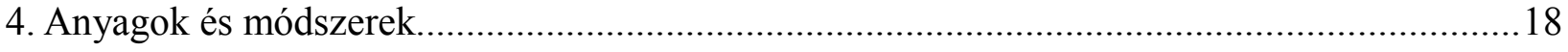

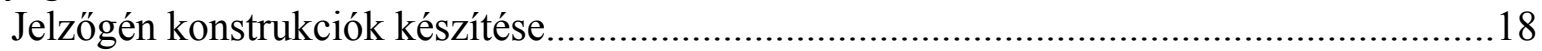

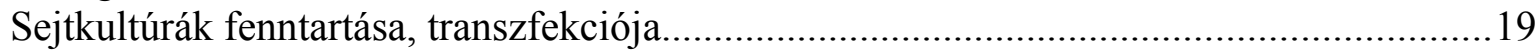

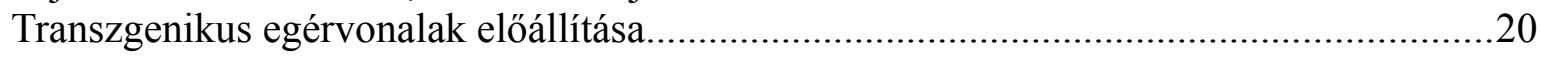

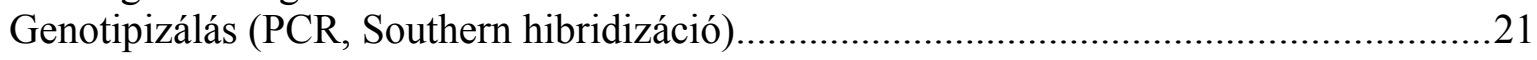

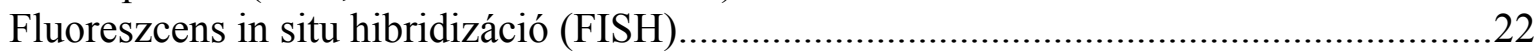

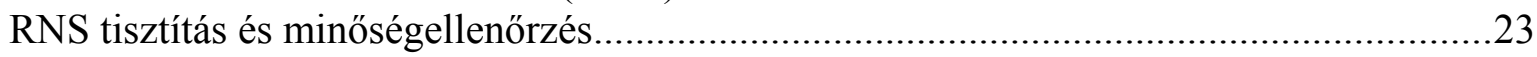

Reverz transzkripcióhoz kapcsolt valósidejü kvantitatív PCR (RT-qPCR)........................24

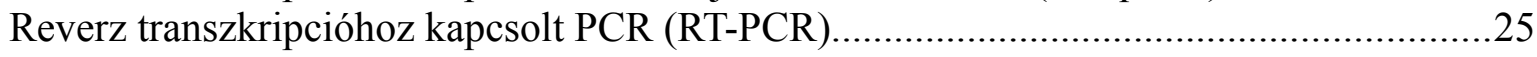

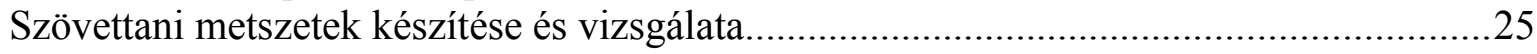

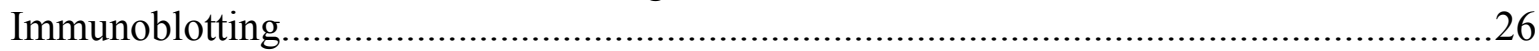

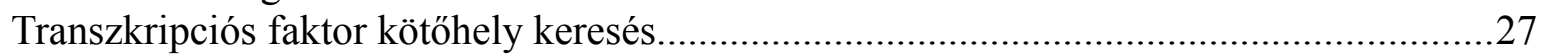

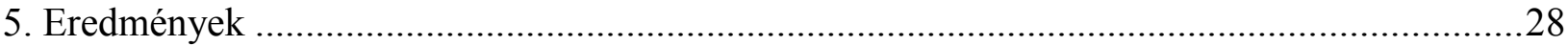

Az izolált ciklin $\mathrm{C}$ promóterdarabok génkifejeződést indukálnak.....................................28

Az egy lókuszú beépülés élő transzgenikus egereket eredményezett...............................29

A jelzőgén kifejeződése gyenge és leginkább a herére korlátozódik..................................33

Ciklin C1 és C2 izoformák minden vizsgált szervben megtalálhatók...............................36

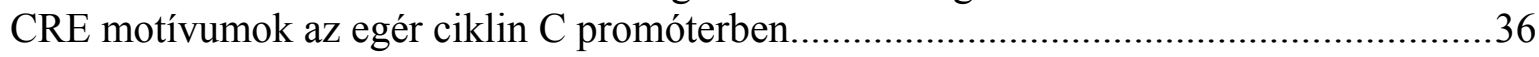

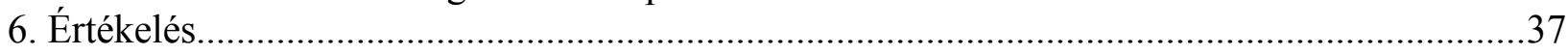

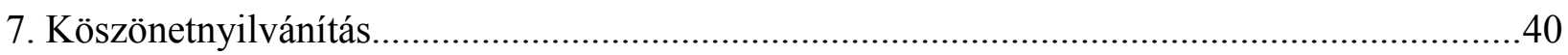

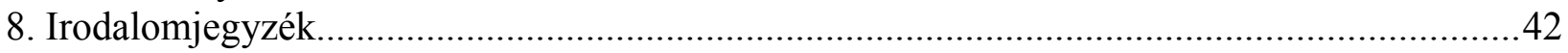

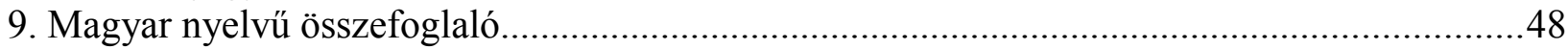

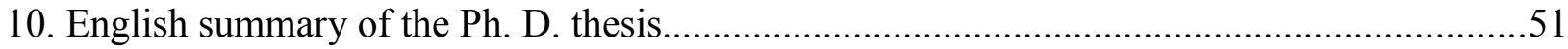




\section{Irodalmi áttekintés}

\section{A ciklinek és a ciklin $C$ gén}

A ciklinek az eukarióta sejtekben található, hasonló szerkezetü és szerepü fehérjék egy csoportját képezik. A csoportot képviselő fehérjék jelentős részének mennyisége a sejtekben a sejtciklus egyes fázisainak ismétlődésével szinkron hullámzást mutat. Éppen ezért a sejtciklus szakaszainak megfelelően és ezekre jellemzően megkülönböztethetünk G1, G1/S, S és M ciklineket. A csoport képviselői leginkább a sejtciklus egyes eseményeinek molekuláris szabályozásában vesznek részt. A ciklinek inaktív, szerin-treonin protein kináz enzimekkel (ciklin-függő kinázok, CDK) heterodimer komplexeket képeznek. Felépítésükre általánosan jellemző, hogy ún. “ciklin box" domént tartalmaznak. Ezen keresztül kötődnek a ciklinek az inaktív kináz partnereikhez, miközben aktiválják azokat. Ily módon, általánosan fehérjéket, fehérje komplexeket foszforilálnak és ezzel adott fehérjéket stabilizálnak, előkészítenek lebontáshoz, aktiválnak vagy gátolnak. Egy ciklin/CDK páros többféle szubsztrátot is köthet, így egyszerre több biokémiai folyamatra is hatással lehet. Sőt, bizonyos ciklinek CDK-kon kívül más fehérjékhez is kapcsolódhatnak.

A ciklin $\mathrm{C}(\mathrm{CCNC})$ is a leírt tulajdonságoknak megfelelö, G1 ciklinek közé sorolható fehérje, amelynek génje emberben a 6q21 $(1,2)$, egérben a 4A3 kromoszóma régiókban található. Léteznek izoformái is, amelyek alternatív RNS szerkesztés (splicing) következtében képződnek (3). Emberben és egérben a legfőbb izoforma 283 aminosavból áll. Csakúgy, mint a ciklin A, T és H két helikális ciklin box domént (4) és az amino terminális véghez közel, az RNS polimeráz IIhoz való közvetlen kötődésért felelős ún. HAD-ot (hholoenzim âsszociációs domén) tartalmaz (5). A CCNC gén az állatvilágban szinte egyedülálló, rendkívül nagy mértékű szerkezeti és funkcionális konzerváltságot mutat. Az ember (Homo sapiens sapiens) és az ecetmuslica (Drosophila melanogaster) ciklin C fehérje ortológjai között például 72\%-os szerkezeti egyezést írtak le 
(6,7). Az ember és a házi egér (Mus musculus) ortológok között (NP_005181.2 és NP_058026.1 fehérjeszekvenciák esetében) pedig még ennél is jóval nagyobb, 99,6\%-os az aminosav szekvencia azonosság. Eddig leírt kináz partnerei a CDK2, 3 és 8, de ezektől függetlenül is részt vesz egyes biokémiai eseményekben. A ciklin $\mathrm{C}$ olyan alapvető sejt- és fejlődésbiológiai folyamatokban szerepel, mint a génátírás, a sejtciklus valamint a sejtadhézió szabályozása (1. ábra).

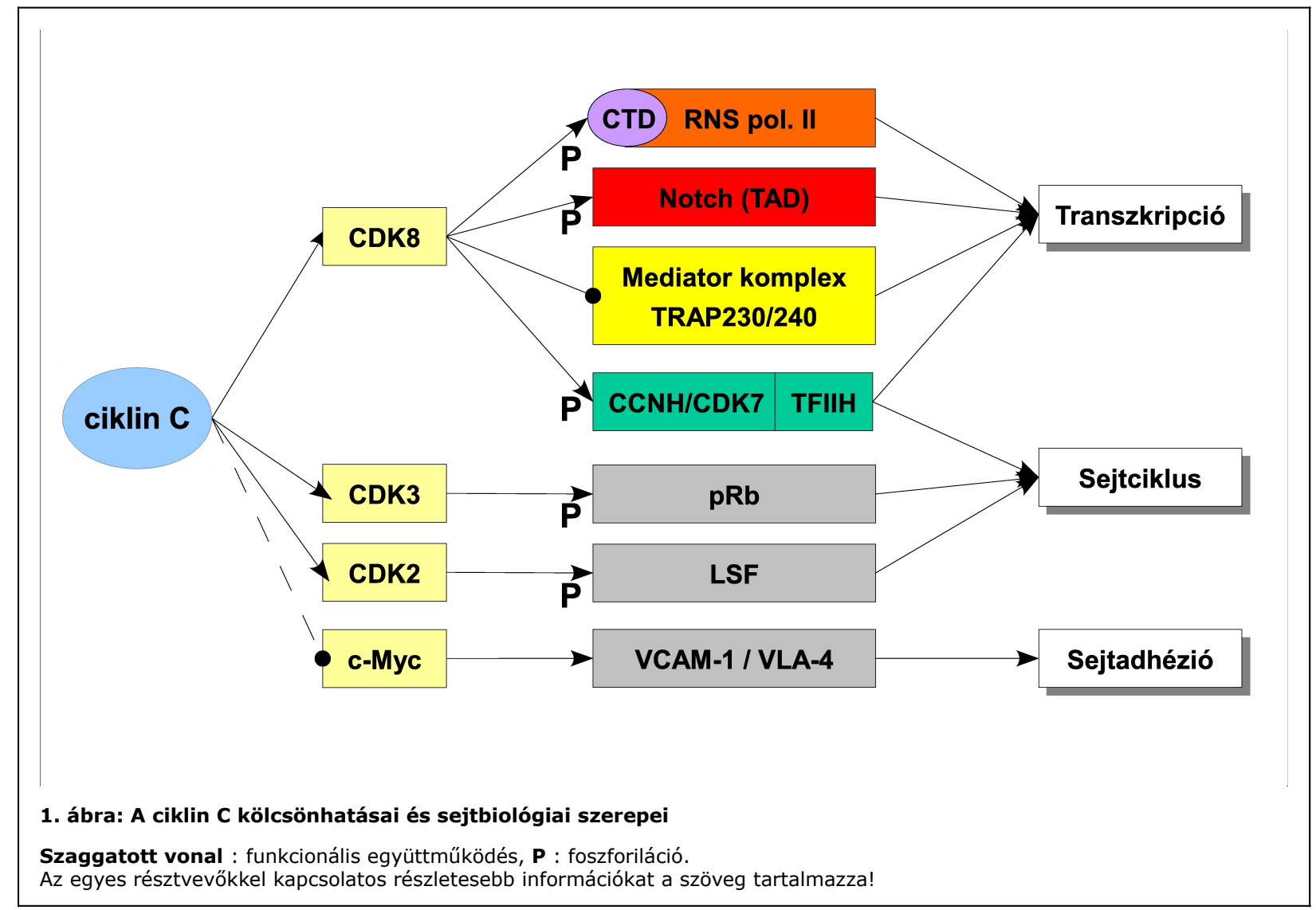

\section{Sejtbiológiai szerepek}

Az emberi ciklin C molekulát először egy sörélesztőben (Saccharomyces cerevisiae) végzett kísérletben fedezték fel, amely képes volt az élesztő mindegyik G1 ciklinjére (CLN1, CLN2, CLN3) mutáns és ezáltal osztódni képtelen, azaz a G1/S átmenetben rekedt törzsét menekíteni (8). A sejtciklust szabályozó szereppel foglalkozó tanulmányok a CCNC-nek elsősorban a G0/G1 és G2/M átmenetekben betöltött funkcióit hangsúlyozzák. Először megfigyelték, hogy a sejtcik- 
lus során a ciklin C hírvivő RNS-ének mennyisége a G0 fázisból történő kilépéskor valamint a G2/M fázisátmenetben a legmagasabb. Kiderült az is, hogy a ciklin $C$ felelős ez utóbbi fázisátmenet szabályozásához kötődő $c d c 2$ (cell division cycle 2) gén indukciójáért is $(9,10)$. Ren és Rollins írták le először emberi T98G és SAOS-2 sejtekben, hogy a ciklin C komplexet alkot a ciklin-dependens kináz 3 (CDK3) enzimmel, amely enzimkomplex a Retinoblastoma (pRb) fehérje 807/811 szerinjeit foszforilálja $(11,12)$. A pRb G0-ban, illetve a korai G1 fázisban inaktivált állapotában megkötve tartja az E2F (adenovirus E2 promoter factor) transzkripciós faktorokat, amelyek a Retinoblastoma $\mathrm{CCNC/CDK3} \mathrm{közvetített} \mathrm{foszforilációja} \mathrm{következtében}$ disszociálnak és aktiválódnak. Ezek a faktorok végül indukálják az S fázisba lépéshez szükséges gének kifejeződését, amely végső soron beindítja a sejtciklust. A CCNC G0/G1 átmenet szabályozó folyamataiban való részvételével kapcsolatban az utóbbi években több közlemény is foglalkozott. Miyata és munkatársai emberi CD34+ köldökvér vagy vérképző őssejtekben (HPSC) megfigyelték, hogy a CCNC lecsendesítése jelentős mértékben megnöveli a G0 fázisban maradó, differenciálatlan HPSC-k számarányát a kontrollhoz viszonyítva (13). Korábban bizonyították a mitózist elhagyó idegsejteknél, hogy a sejtciklusba visszalépés elengedhetetlen a DNS hibák, különösen a kettős száltörések javításának elkezdéséhez (14). Ha patkány idegsejteket az apoptózisukat előidéző trombinnal kezelik, akkor ez a sejtciklus beindulása után G1 fehérjék, azaz a CDK1, -2, -3 valamint CCNC szintjének csökkenésével jár (15). Tomashevski munkatársaival együtt szintén patkányokban felfedezte, hogy a CCNC/CDK3 kináz aktivitás szükséges ahhoz, hogy a kettős szálú DNS törést javító nem-homológ végegyesítési folyamat (non-homologous end joining, NHEJ) aktiválásához a teljesen differenciálódott, nyugvó idegsejtek visszalépjenek G1 fázisba (16). Saxena és munkatársai megállapították, hogy NIH 3T3 egér fibroblasztok korai G1 fázisában a CCNC kötődhet a CDK2 (ciklin-dependens kináz 2) enzimhez is, mivel ahogyan egyes laboratóriumi egér törzsekből, így ezekből a sejtekből is hiányzik a 
CDK3 $(17,18)$. Ez a komplex foszforilálja az LSF (late Simian virus 40 factor) transzkripciós faktort a 309. szerinnél $(17,19)$. Az S309 foszforiláció meggátolja azt, hogy az LSF még a G1 fázisban indukáljon olyan, jellemzően S-fázis géneket, mint például a timidin bioszintézisében kulcsszerepet játszó Tyms (timidilát szintáz).

A ciklin C sejtciklus szabályozással kapcsolatos szerepét különböző klinikai adatok is alátámasztják. Vincent J. Kidd és munkacsoportja a CCNC-t is tartalmazó 6q21 lókusz gyakori delécióját figyelte meg akut limfoid leukémiák egy alcsoportjában. A deléciók többnyire csak az egyik allélt érintették. Feltételezték, hogy az érintett régióban elhelyezkedő CCNC gén tumor szuppresszorként viselkedhetett ezen betegeknél (2). Egy japán kutatócsoport a csontrák egy fajtájában (oszteoszarkómában) a CCNC-t szintén tumor szuppresszornak találta. Megállapították, hogy a vizsgált tumorok jelentős részében is elveszik a 6q16-23 régió. Ezekben a tumorsejtekben a ciklin C RNS szintjének csökkenését is kimérték. Megfigyelték azt is, hogy egy csökkent CCNC expressziójú F-OS nevü csonttumor sejtvonalban egy CCNC-t túltermelő plazmid transzfekciójával jelentős mértékben gátolni lehetett a sejtosztódást (20). Nem tisztázott, hogy a ciklin C egyértelmüen tumor szuppresszornak tekinthetö-e, hiszen vannak olyan közlemények, amelyek bizonyos tumorokban a CCNC emelkedett expressziójáról számolnak be, ami viszont az onkogénekre jellemző tulajdonság. Egy magyar tanulmány bizonyos gyomorrákok (adenokarcinómák) esetében a CCNC RNS szintjét átlagosan 2,8-szorosára, a CDK2 RNS koncentrációját átlagosan 2,5-szörösére emelkedettnek mérte a gyulladásos gyomorfalhoz képest (21). Humán HLE májkarcinóma és BEL-7402 hepatóma sejtvonalak expressziós profiljaiban a ciklin C mRNS koncentrációja emelkedett volt az egészséges májban mért értékekhez viszonyítva $(22,23)$. Továbbá, nemrég közöltek több olyan vizsgálatot is, amelyekben megállapították, hogy a CCNC egyik legjelentősebb kináz partnere, a CDK8 vastagbél, illetve végbél tumorokban onkogénként viselkedik (24-26). Összegezve az idézett klinikai adatokat, sokkal inkább úgy tünik, hogy a 
CCNC szerepe a tumorképződésben tumor- valamint sejttípus függő lehet. Az is elképzelhető, hogy a megfigyelt változások egy része következmény és nem oki tényező.

Az eukarióta transzkripció szabályozásában a ciklin $\mathrm{C}$ több módon is részt vesz. Elsőként a CDK8 kinázzal való kapcsolatát tárták fel. Tassan és munkatársai bebizonyították, hogy a CCNC kötődik egy újonnan azonosított szerin-treonin kinázhoz, a CDK8-hoz in vitro, valamint HeLa sejtekben is megtalálható mind a két fehérje ugyanabban a fehérje komplexben (27). Később kiderült, hogy a CDK8 nemcsak köti, hanem stabilizálja is az amúgy igencsak rövid (kb. 15 perces) féléletidejü CCNC fehérjét (28). Szerkezeti hasonlóságok alapján feltételezték, hogy a CCNC/CDK8 funkciója emlősökben is a sörélesztő SRB11/SRB10 pároséhoz hasonló lehet, amely utóbbi az élesztő RNS polimeráz holoenzim komplex részeként a génátírás szabályozásában vesz részt $(27,29)$. Ezzel nagyjából egy időben közzétették azt is, hogy ecetmuslicában a CCNC/CDK8 is részét képezi az RNS polimeráz II enzim nagy alegységének (30). Ezen belül megtalálható a 25-30 fehérjéből álló, transzkripciós jelátvitelnek egy fontos komponensében, az ún. Mediator komplexben, ahol a MED12 (TRAP230) és MED13 (TRAP240) fehérjékkel együtt az ún. CDK alegységet alkotják $(31,32)$. Igazolták, hogy a CCNC/CDK8 enzimkomplex a sörélesztő SRB11/SRB10 kinázához hasonlóan valóban foszorilálja is az RNS polimeráz II karboxi terminális doménjét (CTD), illetve stabil és müködőképes marad a teljes sejtciklus időtartama alatt (9,33). A CTD egy Tyr-Ser-Pro-Thr-Ser-Pro-Ser heptapeptid ismétlődő egységekből álló motívuma az RNS polimeráz II-nek. Korábban kimutatták, hogy ennek a régiónak a foszforilációja mintegy bekapcsolja az RNS polimerázt és ily módon járul hozzá a transzkripció elindításához (34). A CTD-n elkülöníthetők kitüntetett foszforilációs helyek, amelyeknek eltérő szerepe van a hírvivő RNS-ek szintézisében. Megkülönböztethetünk a promóterek szabaddá tételéért (promoter clearance), hatékony elongációért, illetve bizonyos esetekben génfüggő átírásért vagy a represszióért is felelős helyeket és foszforilációs mintázatokat (35). Mindezek mellett a CTD 
hiperfoszforilációjával a sejt befolyásolni képes az mRNS-ek érési folyamatait is, úgymint az RNS szerkesztést (splicing) vagy poliadenilációt (36,37). A CCNC/CDK8 kináz a 2-es és 5-ös szerinekre helyez foszfátcsoportot (38). Elöször azt gondolták, hogy ilyen módon csak a génátírás elindítását (iniciációt) gátolja (39), de később egyre több cikk igazolta, hogy egyes helyzetekben transzkripciót aktiváló hatása is van (40-43). A ciklin C/CDK8 komplex továbbá képes foszforilálni a TFIIH (general transcription factor II H) ciklin H alegységének Ser-5 és Ser-304 aminosavait, amellyel gátolja a TFIIH CTD-kináz aktivitását és végső soron a transzkripciót (44). Egy amerikai csoport feltárta azt is, hogy a CCNC/CDK8 komplex a Notch jelátviteli útvonalban is közremüködik. Korábbi tanulmányokból ismertté vált, hogy a Notch sejtfelszíni receptor komplex aktiválása szabályozott fehérjebontási lépéseken megy keresztül, melynek eredményeképpen a komplex sejten belüli része (intracellular domain, ICD) lehasad, és a Mastermind valamint CBF1 fehérjékkel asszociálva géneket aktivál. A CCNC/CDK8 komplex a Notch ICD transzkripció aktiváló doménjénak (TAD) PEST motívumán keresztül az ICD-t hiperfoszforilálja és ezáltal elősegíti annak proteoszómális lebontását. Ezzel indirekt módon gátolja bizonyos gének, mint pl. a gerincesek szomita képződését szabályozó HES1 (Hairy/Enhancer of split) represszor gén aktivációját (45).

A ciklin C sejt-sejt kapcsolat kialakításakor is közremüködhet. Egy japán kutatócsoport először megfigyelte azt, hogy ha a ciklin C és c-Myc (myelocytomatosis oncogene) géneket plazmidról egyszerre fejezteti ki IL-3 (interleukin 3) függő emberi BAF-B03 vérképző sejtvonalban, akkor ez aggregációra készteti ezeket a sejteket amellett, hogy citokin függetlenné teszi osztódásukat (10). Nem sokkal később leírták azt is, hogy ennek a folyamatnak, azaz a homotipikus sejtadhéziónak a hátterében a VCAM-1 (vascular cell a adhesion molecule 1) és a VLA-4 (very late antigen 4) integrinek egymástól független aktivációja áll (46). A G1 ciklinek (ciklin C, D, E) közül ez a tulajdonság egyedül a ciklin C-re jellemző és nem köthető CDK aktivitáshoz sem. 


\section{Fejlődésbiológiai szerepek}

A tárgyalt sejtbiológiai mechanizmusok, mint a génátírás, a sejtciklus valamint a sejtadhézió szabályozása alapvető részeit képzik az egyedfejlődés során lezajló programoknak. Egyre több direkt és indirekt bizonyíték lát napvilágot, amelyek mind jobban hangsúlyozzák a CCNC jelentőségét az eukarióta szervezetek egyedfejlődésében is.

Egy talajlakó amőbafaj, a sejtes nyálkapenész (Dictyostelium discoideum) bár alapvetően nem soksejtű szervezet, éhezés során átvált soksejtü életciklusra és spóraképzésre. A soksejtüség az egyes sejtek aggregációjának következményként jön létre. Megfigyelték, hogy ha a DdCdk8 (Dictyostelium CDK8) fehérje, a CCNC egyik jelentős kináz partnere hiányzik ebből az amőbából, akkor - bár a sejtek életképesek maradnak - a Dictyostelium képtelen az aggregációra (47). Ezen túlmenően nem képez spórákat sem, ami inkább a DdCdk8 differenciációban betöltött szerepét hangsúlyozza (48). A tápanyaghiány miatt a nyálkapenész sejtek a külső környezetükbe cAMP-t (ciklikus adenozin monofoszfát) bocsátanak ki és kemotaxis útján egymáshoz vonzódnak. A magas extracelluláris cAMP koncentráció következtében és a soksejtüvé válás közben a sejtek intracelluláris cAMP szintje is megnövekszik. Ennek hatására a soksejtü állapotú nyálkapenészben a magas intracelluláris cAMP szint miatt a CCNC szintje lecsökken, amelynek eredményeképp kevesebb aktív CCNC/DdCdk8 komplex képződik. Ha a CCNC-t és/vagy DdCdk8at túltermelik, az korai fejlődési stádiumok gyors lezajlásához vezet (49). Mindezek az adatok arra utalnak, hogy a CCNC és DdCdk8 a Dictyostelium korai fejlödési, sejtsors meghatározási folyamatainak időzítésében is részt vehet.

A Drosophila melanogaster $\mathrm{CCNC}^{-/-}$mutánsok korai báb stádiumban elpusztulnak és ennek az állapotnak csak részleges menekítését sikerült elérni egy mindenhol kifejeződő, egy allélos transzgenikus ciklin C expresszióval. Az így kifejlődő imágókban érzékszőr és szexfésű deformitások mutatkoznak. Két transzgenikus allél már elegendő a teljes menekítéshez. A homozigóta 
CDK $8^{\mathrm{K} 185}$ funkcióvesztéses mutánsok sem fejlődtek tovább a késői harmadik lárva (L3) stádiumnál. A mutánsok előállítása és vizsgálata során az is bebizonyosodott, hogy bár a fejlődő, fenti mutációkat hordozó ecetmuslica bábok és lárvák nem fejlődnek tovább és életképtelenek, ez az állapot mégsem befolyásolja sejtjeik életképességét (50).

Gerincesek közül a zebradániónál (Danio rerio) leírták, hogy a CDK8 RNS-e a szegmentációs stádiumban (megtermékenyítés utáni 10-24. órában) mindenhol jelen van, de jelenléte a zsigerív stádiumban (24-48. óra) a feji és nyaki régióra, illetve kismértékben a farokra korlátozódik, amely már aktív, szövetspecifikus, embrionális génátírásra utal (51). A szövetspecifikusság az egyedfejlődésben azt sugallja, hogy feltehetően a CDK8 csak jól meghatározott fejlődési programokban, differenciálódási lépésekben aktív.

Házi egérben (Mus musculus) a CDK8 aktivitás hiánya (funkcióvesztéses mutációja) következtében az embriók még beágyazódás előtt, 2,5-3 napos embrionális korban (E2,5-E3) elpusztulnak. Ezzel szemben a heterozigóta $\left(\mathrm{CDK}^{+/}\right)$hordozó állapotnak nincsen semmiféle fenotípusos következménye. A CDK $8^{-/-}$embriókban a hólyagcsíra blasztomérái szétdarabolódnak. Vélhetően a CDK8 a transzkripciós szabályozáson keresztül inkább a korai sejtsors meghatározásban vehet részt, hiszen hiányának nincs számottevő hatása a sejtek osztódó-, illetve életképességére (52).

A CCNC génkiütött egerek (2. ábra) a CDK8 mutánsokhoz hasonlóan embrionális elhalálozást mutatnak, de ezen egér embriók elörehaladottabb kort érnek meg, hiszen lezajlik a beágyazódás és elindul a méhlepény képződés, illetve morfogenezis is. Bizonyos differenciálódási folyamatok is elkezdődnek, de összességében a további fejlődés lelassul és az embrionális 8,5-10,5 (E8,5E10,5) napon megreked (Katona és munkatársai, nem közölt eredmények, (53)). A CDK8 ${ }^{+/-}$ egerekhez hasonlóan a $\mathrm{CCNC}^{+-}$egerek fenotípusa is a vad típusúnak felel meg. A 9,5 napos CCNC hiányos embriók jóval kisebbek heterozigóta vagy vad típusú testvéreikhez képest. 


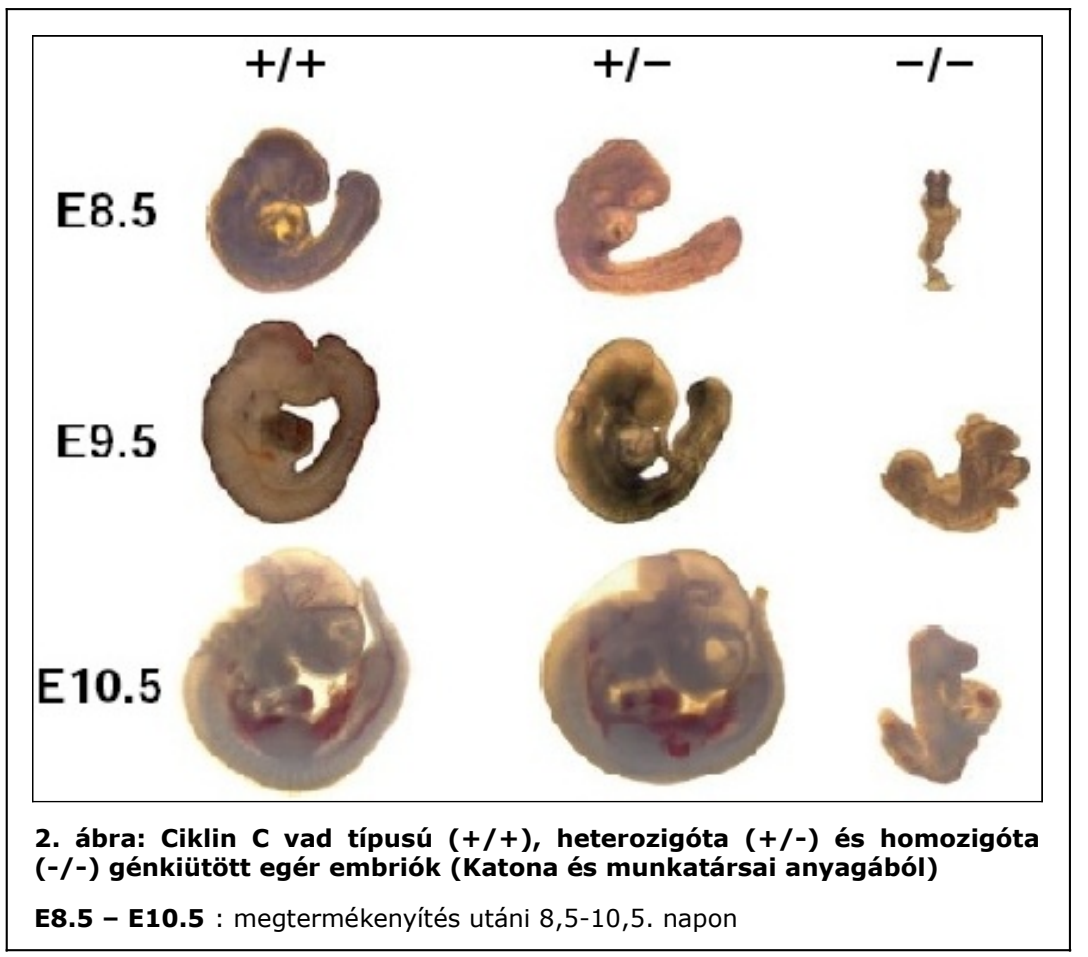

Mellső végtagkezdeményeik fejletlenek. Hátsó végtagkezdeményeik nem alakulnak ki. Farki részük csökevényes. A szív nagy méretüre duzzad és amorffá válik valamint megfigyelhető még az embrionális velőcső feji záródási rendellenessége is. Érdekes módon úgy tünik, hogy a CDK8 mutánsok-

kal azonos módon a sejtosztódás ezekben az egér embriókban sem érintett. Zavart szenved viszont a ér- és a méhlepény képződés is. Elképzelhető, hogy inkább ez utóbbiak következményeként fellépő általános oxigénhiány és a leírt fokozott apoptóziskészség lehet az oka az eltérések egy részének vagy egészének $(53,54)$.

A fentebb részletezett sejt- és fejlődésbiológiai kísérletek eredményeit összegezve kijelenthető, hogy a ciklin C több biokémiai útvonalon keresztül is érintett lehet az egyedfejlődés szabályozásában. Ezt a szabályozást úgy tünik, hogy leginkább gének indukcióján és represszióján keresztül végzi. Az ecetmuslicában és egérben végzett megfigyelések arra utalnak, hogy a ciklin $\mathrm{C}$ fehérjének már az embrionális fejlődés kezdeti szakaszában alapvető jelentősége van és ezek az eredmények még azt is sugallják, hogy ez a szabályozás csak meghatározott szövet- vagy sejttípusokra, illetve bizonyos embrionális stádiumokra korlátozódhat. Tovább erősítheti ez utóbbi feltételezést is az a tény, hogy egy átfogó transzkriptom atlasz készítése során 14,5 napos korú egér embrióban (E14,5) a ciklin C RNS-ét nem sikerült kimutatni (55). Elképzelhető, hogy azért, mert a CCNC ebben a stádiumban (már/még) nem expresszálódik, de ennek ellenére nem lehet kizárni 
annak a lehetőségét sem, hogy az embrionális fejlődés során olyan alacsony szintű RNS koncentrációkkal kell számolni, amelynek kimutatásához nem elég érzékeny az alkalmazott RNS in situ hibridizációs technika.

\section{A ciklin C kifejeződésének szabályozása}

Ahhoz, hogy jobban megérthessük a CCNC magasabb rendü eukarióta sejtekben, illetve szöveti, szervi szinten betöltött szerepét, létfontosságú ismerni és számításba venni a ciklin C sejt- és fejlődésbiológiai funkcióin túl azokat a tényezőket is, amelyek a ciklin C kifejeződését befolyásolják.

A ciklin $\mathrm{C}$ fehérje féléletideje önmagában meglehetösen rövid (kb. 15 perc) és lebontásra kerül az ubiquitin-proteaszóma útvonalon keresztül. Intracelluláris mennyisége nagyban függ a CDK partnerhez való kötődéstől (28), illetve hírvivő RNS-ének mennyiségétől $(49,56,57)$. Úgy tünik, hogy humán T limfoblaszt (CEM sejtvonal) és ecetmuslica embrionális sejtekben a sejtciklusban a CCNC fehérje mennyisége számottevően nem változik $(9,30)$, azonban humán vérképző őssejt és bőr fibroblaszt sejtekben az RNS-ének mennyisége sejtciklussal szinkron hullámzást mutat és leginkább a G0/G1/S valamint a G2/M átmenetekben tetőzik $(10,56)$. Elképzelhető, hogy a CCNC mRNS szintjének növekedését nem követi a ciklin C koncentráció jelentős emelkedése, ha nincs, ami az újonnan képződött CCNC-t stabilizálja. Mindenesetre, az elérhető szabad CCNC fehérjemolekulák mennyiségét a transzkripció, RNS érés/lebontás üteme is megszabja.

A ciklin $C$ génátírásra ható tényezőket emberi sejtkultúrákon végzett, in vitro kísérletek során fedezték fel (3. ábra). Először egy MCF-7 nevü humán emlőkarcinóma sejtvonalban megállapították, hogy a $D_{3}$ vitamin és ennek szintetikus analógjai (EB1089 és CB1093) jelentősen megnövelik a ciklin C RNS, illetve fehérje szintü kifejeződését is. Ezt a hatást ugyanúgy meg lehetett figyelni MeWo melanóma és U937 leukémia sejtekben is (58). Később 
megállapították, hogy ennek

a jelenségnek a hátterében a ciklin C promóterében jelenlevő és működőképes

VDRE-k (

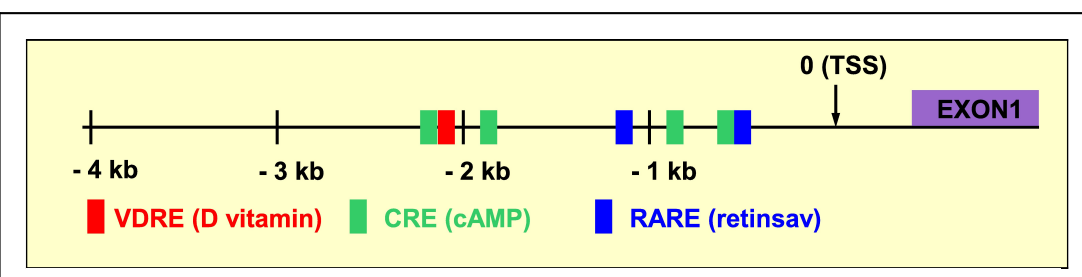

3. ábra: Az emberi ciklin C promóter

TSS : transzkripciós startpont, VDRE : D vitamin reszponzív elem kötőhely, CRE : cAMP reszponzív elem kötőhely, RARE : transz retinsav reszponzív elem kötőhely

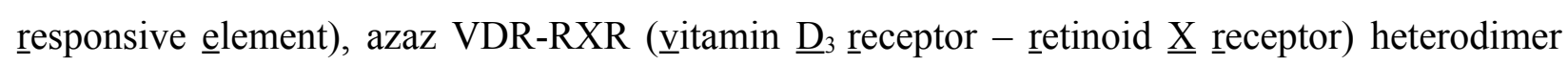
kötőhelyek állnak. Az emberi CCNC promóterben négy ilyen elemet fedeztek fel a transzkripciós startponttól (TS) számított -2080, -5560, -6955 és -8284 nukleotid pozícióknál. A legerősebb a -2080-as pozícióban levő elem, amelyről feltételezték, hogy önmagában is elegendő, hogy közvetítse a $D_{3}$ vitamin ciklin $C$ átírásra kifejtett teljes hatását (59). Mindezeken túl a megnövekedett intracelluláris cAMP (Forskolin hatására) és ATRA (âll-trans retinoic acid vagy transz retinsav) is képes indukálni a ciklin C gént MCF-7 emlődaganat és HEK293 adenovírus transzformált humán embrionális vesesejtekben. Az emberi CCNC promóter TS melletti 2250 bázispár méretü szakaszán a -595, -855, -1976 és -2231 helyeken CRE-ket (ㄸAMP responsive elements), illetve a -550 és -1160 pozíciókban funkcionális RARE-ket ( elements) azonosítottak. A hozzájuk kötődő transzkripciós faktorok, a CREB1 (ㄸAMP responsive element binding protein 1 ) és RAR $\gamma$ (retinoic acid receptor gamma) egymással indirekt módon vélhetően a kromatin felnyitásán és a másik kötőhelyeinek elérhetővé tételén keresztül kölcsönösen is együttmüködnek. A sejtek a kromatin módosításával, pontosabban a hiszton fehérjék deacetilációján keresztül, a hiszton-kód módosításával is befolyásolják a CCNC expressziót. Ebben a folyamatban represszorként a HDAC6 (histon deacetylase), illetve aktivátorként pedig a HDAC1, HDAC5, HDAC7 és HDAC11 játszanak szerepet. Igazolták azt is, hogy a cAMP és a transz retinsav sejtciklusra kifejtett hatásai a CCNC-től függnek, illetve leginkább rajta keresztül érvényesülnek (60). 
Gerincesekben kevés adat áll rendelkezésre a ciklin C transzkripciójának térbeli szabályozásáról, illetve arról, hogy az egyes szövetek és szervek szintjén hogyan értelmezhető ennek a nagyfokú pleiotrópiát mutató génnek a funkciója. Egy közelmúltban megjelent tanulmány szerint az emberi CCNC két, alternatív RNS szerkesztéssel létrejövő különböző izoformája (CCNC1 és CCNC2) eltérő térbeli RNS mintázatot ad. Míg az 1-es izoforma minden vizsgált szervben kis koncentráció különbségekkel van jelen, addig a 2-es izoforma expressziója jóval hangsúlyosabb a herében, agyban és az emlőmirigyben a többi szervhez képest (56). Ez az eltérés felveti annak lehetőségét, hogy a ciklin C expressziós szabályozását eddig még nem ismert úton az RNS érés, és az RNS interferencia is befolyásolhatja szerv-, illetve szövetspecifikus módon. 


\section{Célkitűzések}

A bevezetőben tárgyalt adatokra alapozva feltehető, hogy emlösökben a CCNC génexpressziós és sejtciklus szabályozáson keresztül sejtsorsok meghatározásával vehet részt az egyedfejlődési programokban. Ezt a feltételezést alátámasztja, hogy a CCNC/CDK8 komplex a szomitaképződésben szereplő HES1 represszor gén indukcióját gátolja a Notch jelátviteli útvonalban (45) valamint az a tény, hogy CCNC csendesítés következtében a CD34+ köldökvér vagy vérképzö őssejtek jelentős része nem hagyja el a G0 fázist és differenciáltalan marad (13). Az állatvilágban kivételesen nagymértékü strukturális és funkcionális konzerváltság miatt valószínüsíthető, hogy a Dictyosteliumban megfigyeltekkel analóg módon a ciklin C expressziója magasabbrendủ eukariótákban is az egyes fejlődési eseményekhez kötötten, az adott sejtek mikrokörnyezetétől, esetleg sejttípustól függően és időzítetten zajlik. Erre enged következtetni az a megfigyelés is, hogy a CCNC gén-kiütött embriókban az egyes szövetek fejlődése elindul, de morfológiai állapota különböző fokú lemaradást mutat a vad típusú kortársakhoz képest. A 9,5 napos embriókban az érképződésben súlyos hiányosságok mutatkoznak, míg pl. a mellső végtagok, a velőcső és a szív fejlődése elkezdődik (53). A ciklin C fehérjének a gerincesek fejlődésében és felnőtt életében betöltött szerepével kapcsolatban azonban még számos kérdés megválaszolatlan. Nem ismert, hogy a CCNC-nek az emlősök élete során a zebradánió CDK8 térbeli és időbeli expressziós mintázatához (51) hasonlóan ténylegesen van-e szövet vagy sejttípus specifitása. Az ismert génexpressziós adatbázisok (61) kevés sejt- és fejlődési stádium specifikus adatot tartalmaznak a ciklin C génkifejeződésével kapcsolatban. Nem tudjuk, hogy a tárgyalt sejtbiológiai funkciók az egyedfejlődés során hol és mikor érvényesülhetnek. Bár in vitro emberi sejtkultúrákon végzett kísérleti eredmények alapján a retinsav (A vitamin), $\mathrm{D}_{3}$ vitamin és a cAMP biztosan hatással vannak a ciklin $\mathrm{C}$ átírására (58-60), ezen tényezők összesített hatása a CCNC expressziójára nézve megjósolhatatlan. Továbbá várható, hogy újabb, még eddig ismeretlen tényezők hatásaival is számolni kell. Az 
eddig megismert, CCNC génátírást szabályozó faktorok közül a $\mathrm{D}_{3}$ vitaminra adott válaszhoz feltehetően elegendő a -2080-as pozícióban található kötőhely jelenléte. A retinsav és cAMP esetében is a transzkripciós startponttól $5^{\prime}$ irányban elhelyezkedő, kb. 3 kilobázis méretủ régió közvetíti ezen faktorok transzkripciós válaszát, így elképzelhető, hogy ez a DNS szakasz tartalmazza a teljes CCNC promótert is, de erre vonatkozóan sincs kísérletes adat. Ezek ismeretében a következő kérdéseket tettük fel:

1. Azonosíthatók-e olyan újabb részei a CCNC promóternek, amelyek befolyásolják a gén átírását emlős sejtekben?

2. Az egér CCNC transzlációs startpontja mellett 5' irányban levő 3,6 kilobázis hosszúságú DNS szakasz, amely 3,4 kb promóterdarabból és 173 bázispárnyi 5'UTR-ből (unntranslated region) áll, elegendő-e ahhoz, hogy a ciklin C-re jellemző térbeli expressziós mintázatot kialakítsa?

3. Felhasználható-e ez a DNS szakasz egy riporter rendszerben a ciklin C expresszió térbeli és időbeli követésére?

4. Felnőtt egerekben milyen a ciklin $\mathrm{C} 1$ és $\mathrm{C} 2$ térbeli transzkripciós mintázata és ez összevethető-e az emberivel valamint a jelzőgén által kialakított mintázattal?

Ezen kérdések megválaszolásához a házi egeret (Mus musculus) terveztük modellszervezetként használni. A CCNC transzkripciós startpontjával 5' irányban szomszédos, különböző hosszúságú fragmentumokat vagyis a CCNC promóter szakaszokat a megfelelő egér BAC klónból terveztük kivágni. Ezekhez a hrGFP (humanized ㅁenilla reniformis green fluorescent protein) kódoló szekvenciáját az SV40 ( Simian virus $\underline{40}$ ) polyA (poliadenilációs) jelével együtt a fragmentektől 3' irányban, azokkal tandem orientációban kívántuk hozzáépíteni. Az így kapott, ún. jelzőgén 
konstrukciókat emlős sejtekbe bejuttatva fluoreszcens mikroszkóp segítségével szándékoztuk leellenőrizni azt, hogy az említett módosított/módosítatlan promóterdarab képes-e a hozzáépített jelzőgén expresszióját elősegíteni. A továbbiakban a 3,4 kb hosszúságú CCNC promóter5'UTR-hrGFP-polyA konstrukciót tartalmazó DNS fragmentumot a plazmidból történt kivágás után megtermékenyített egér petesejtek hím előmagjaiba injektálva hrGFP-t jelzőgénként kifejező, transzgenikus egérvonalak létrehozását céloztuk meg. A transzgén jelenlétét és kromoszómális integrációját az injektált DNS szekvenciára specifikus PCR reakciókkal, Southern hibridizációval, valamint kromoszóma FISH (fluoreszcens in situ hibridizáció) technikával terveztük ellenőrizni. Ivarérett felnőtt egyedek szerveiben a hrGFP mRNS-ét reverz transzkripció kapcsolt kvantitatív PCR, fehérjetermékét pedig fluoreszcens mikroszkópia valamint immunoblotting módszerek alkalmazásával kívántuk kimutatni. A ciklin $\mathrm{C}$ izoformák hírvivő RNS-einek mennyiségét is reverz transzkripció kapcsolt kvantitatív PCR-rel szándékoztuk megmérni. 


\section{Anyagok és módszerek}

\section{Jelzőgén konstrukciók készítése}

Különböző hosszúságú egér ciklin $\mathrm{C}$ promóterszakaszokat és hrGFP jelzőgént tartalmazó konstrukciókat készítettünk el (4. ábra). A promóterdarabok klónozásánál a 80628 számú BAC (bacterial artificial chromosome) klónt (Genome Systems, Inc., St. Louis, MA) vettük alapul, amely az egér 4-es kromoszómájának A3-as régiójából egy 147 kilobázis méretü DNS szakaszt hordoz. Ez a teljes ciklin $\mathrm{C}$ gént az 5' és 3' szomszédos régiókkal együtt tartalmazza. A DNS fragmentek klónozásához a pBluescript II SK+ (Stratagene 212205) plazmidot használtuk célvektornak. Az első plazmid (pCChrGFP1) úgy készült, hogy először az egér ciklin C promóterének egy 3339 bázispár hosszúságú, a transzkripciós startponttól -59 bázispárnyira végződő (azaz 58 bázispárnyi proximális promóter deléciót tartalmazó) szakaszát a pBluescript II SK+ vektorba, NotI-BamHI restrikciós emésztőhelyek közé építettük. Az így kapott plazmidba a BamHI-EcoRV helyek közé ligáltuk a phrGFP-1 (Stratagene 240059) vektorból BamHI-SspI kettős emésztéssel kivágott hrGFP leolvasási keretet és SV40 poliadenilációs szignált tartalmazó DNS darabot. A másik konstrukció (pP3CG, GenBank azonosító: HQ873320) az előbbire alapozva készült úgy, hogy PCR reakcióval felsokszoroztuk és a pCChrGFP1-ben kipótoltuk a CCNC promóter 3' végéről hiányzó 58 bázispár és az 5'UTR 173 bázispár hosszúságú szakaszát.

Egy nagyobb, 10,6 kb méretü promóterdarabot tartalmazó plazmidot (pP10CG) a pP3CG kibőví-

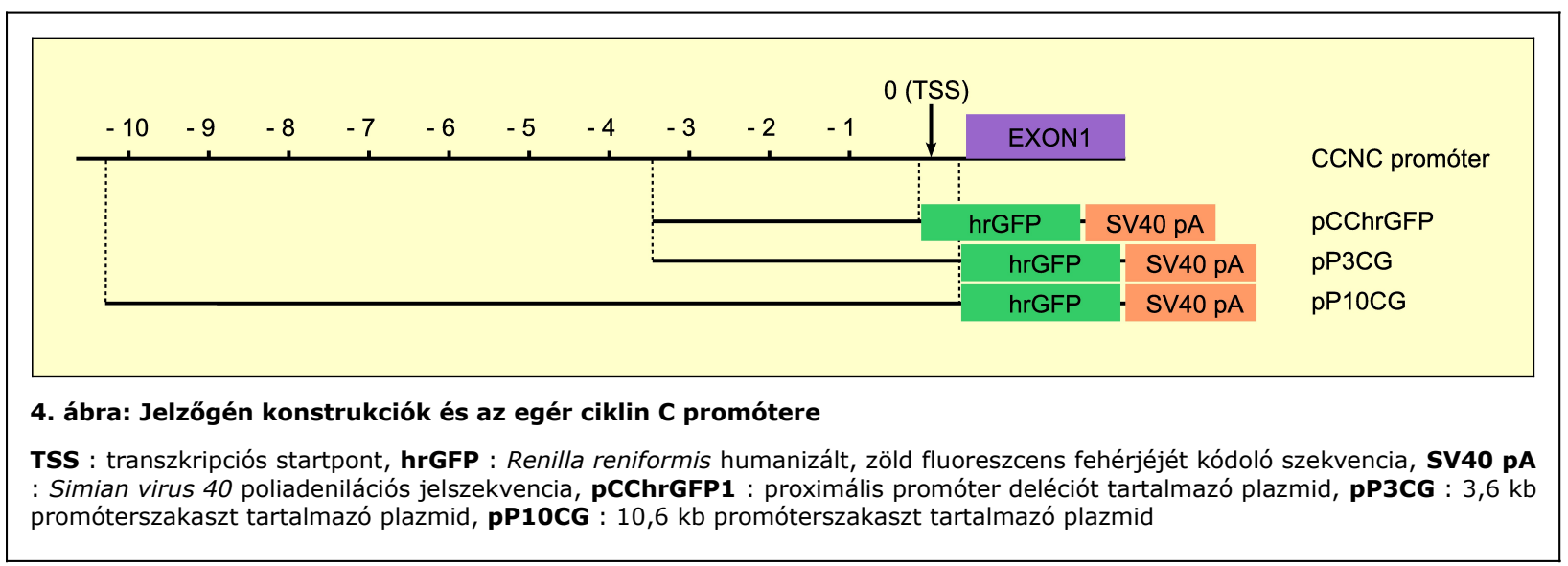


tésével állítottunk elő. A 3.6 kilobázis hosszúságú ciklin C promóterdarabban lévő NheI restrikciós enzim felismerőhelytől 5' irányban található promóterszakaszt lecseréltük az egér genomikus DNS-ének megfelelő régiójából származó 10369 bázispár méretü, SnaBI-NheI helyek által határolt fragmentummal. Az elkészült konstrukcióknál restrikciós emésztéssel és kapilláris szekvenálással is ellenőriztük a beépített ciklin $\mathrm{C}$ promóter részek jelenlétét, illetve szekvenciáját. A molekuláris klónozási lépésekhez DH5a E. coli kompetens baktériumtörzset (Invitrogen 18265-017), New England Biolabs és Fermentas cégek által forgalmazott restrikciós endonukleázokat és T4 DNS ligázt használtunk. A PCR reakciókhoz a GoTaq Flexi kitet alkalmaztuk (Promega, M8301). A jelzőgén vektorok építésénél az egyes munkafázisokban (transzformáció, szelekció, plazmid, illetve DNS fragment tisztítás) a „Molecular cloning: a laboratory manual” címü könyvben foglaltakat tekintettük irányadónak (62).

\section{Sejtkultúrák fenntartása, transzfekciója}

A plazmidok transzfektálását és expressziójának ellenőrzését 293FT emberi vesesejt (Invitrogen R700-07) és P19 egér embrionális teratokarcinóma (ATCC azonosító: CRL-1825) kultúrákon, közel azonos kiindulási sejtszámmal végeztük. A 293FT kultúrákat a forgalmazó által ajánlott módon magas glükóztartalmú DMEM (Dulbecco's Modified Eagle Medium) (Invitrogen 11965092), 10 v/v \% magzati szarvasmarha savó (Fetal Bovine Serum, FBS) (Invitrogen 16000-044), $0.1 \mathrm{mM}$ nem esszenciális aminosav készítmény (Invitrogen 11140-035), 2 mM L-glutamin (Invitrogen 25030-081), 1x Penicillin-Streptomycin (Invitrogen 15070-063) és $500 \mu \mathrm{g} / \mathrm{ml}$ Geneticin (Invitrogen 10131-035) tartalmú tápoldatban tartottuk fent. A P19 sejteket DMEM (Dulbecco's Modified Eagle Medium) (Invitrogen 11965-092), 10 v/v \% magzati szarvasmarha savó (Fetal Bovine Serum, FBS) (Invitrogen 16000-044), 2 mM L-glutamin (Invitrogen 25030081) és 1x Penicillin-Streptomycin (Invitrogen 15070-063) tartalmú oldatban szaporítottuk. Mindkét sejtkultúrát $37{ }^{\circ} \mathrm{C}$-on $5 \mathrm{v} / \mathrm{v} \quad \%$-os $\quad \mathrm{CO}_{2}$ koncentráció mellett tenyésztettük. A 
transzfekciókat $8 \mu \mathrm{g}$ plazmiddal, $6 \mathrm{~cm}$ átmérőjü, kerek Petri-csészében $20 \mu \mathrm{l}$ Lipofectamine 2000 (Invitrogen 11668-027) reagens segítségével végeztük a gyártó által mellékelt útmutató szerint. A jelzőgén expresszióját 24 és 48 órával a transzfekció után Olympus Vanox-S fluoreszcens mikroszkóppal vizsgáltuk.

\section{Transzgenikus egérvonalak előállítása}

Ehhez a pP3CG plazmidból ApaLI emésztéssel kivágtuk a 3581 bázispár méretű egér CCNC promóter-5'UTR - hrGFP - SV40 polyA kazettát tartalmazó, összesen 6494 bázispár hosszúságú DNS darabot és kitisztítottuk a QIAquick Gel Extraction kit (QIAgen 28706) segítségével (5. ábra). Ezt a jelzőgén - a továbbiakban P3CG - kazettát tartalmazó oldatot $3 \mathrm{ng} / \mu 1$ töménységüre hígítottuk. A P3CG fragmentumot boroszilikát mikrokapilláris segítségével FVB/N egér zigóták hím előmagjaiba juttattuk. Az injektálást túlélő zigótákat steril hímekkel pároztatott, fél napos álterhes CD1 nőstény egerek petevezetőibe ültettük be. A megszületett, kifejlődött egerekben ellenőriztük a P3CG transzgén jelenlétét (genotipizálást lásd alábbiakban) és a hordozókat ( $\mathrm{F}_{0}$ generáció) $\mathrm{FVB} / \mathrm{N}$ egerekkel pároztattuk. A pároztatásból kapott transzgenikus heterozigóta testvéreket ( $\mathrm{F}_{1}$ generáció) tovább pároztattuk annak érdekében, hogy P3CG homozigóta egyedeket állítsunk elő. Az így kapott, lehetséges homozigóta jelölteket tesztelő keresztezésben FVB/N (vad típusú) egyedekkel pároztattuk. Egy-egy kérdéses egér legalább 20 utódját megvizsgáltuk és akkor tekintettük ténylegesen P3CG homozigótának, ha minden utódját hordozónak találtuk. P3CG

BS-probe-5'
5. ábra: az injektált P3CG transzgén és a kimutatásához használt PCR primerek, próbák elhelyezkedése
P-3.6kb-CCNC : az egér ciklin C promóteréből 3397 és 5'UTR-ből 174 nukleotidot tartalmazó 3,6 kb méretú DNS szakasz;
BS-probe PCR : 499bp méretú amplikon, amely PCR reakció során a transzgén 5' végérőll képzódik; BS-probe-5': BS-probe
PCR 5' végi primere; T3 RC : BS-probe PCR 3' végi primere, a T3 szekvencia reverz komplementere; hrGFP PCR : 651bp
hosszúságú amplikon, amely PCR reakció során a transzgén fragment hrGFP-t kódoló részéről képződik. Ezt a PCR terméket
Southern blotting és FISH kísérleteknél hibridizációs próbaként is használtuk.
hrGFP-5' : hrGFP PCR 5' végi primere; hrGFP-3' : hrGFP PCR 3' végi primere


homozigóta hím és nőstény testvérek pároztatásával transzgenikus vonalakat alapítottunk, amelyeket $\mathrm{P} 3 \mathrm{CG}+\mathrm{F}_{0}$ generáció alapító egyed sorszámával jelöltünk. Az állatokon végzett beavatkozásokat mindenkor a hatályos magyar állatvédelmi törvény és az állatházi házirend elöírásainak betartásával, kíméletesen, illetve megfelelő mélységű altatásban végeztük. A transzgenikus vonalak előállításánál Nagy András és munkatársai által javasoltaknak megfelelően jártunk el (63).

\section{Genotipizálás (PCR, Southern hibridizáció)}

A vizsgálathoz szükséges genomikus DNS-t az egerek farki végéböl tisztítottuk Wizard Genomic DNA Purification kit segítségével (Promega A1125). A P3CG transzgén jelenlétét specifikus polimeráz láncreakciókkal mutattuk ki, amelyhez a GoTaq Flexi DNA Polymerase kit-et (Promega M8301) használtuk. A következő primerpárokat alkalmaztuk (5. ábra) a 651 bp méretű hrGFP szekvenciánál: 5'-GAGATCATGAGCTTCAAGGT-3', 5'-CTTGCCCAGGCTGGTCAGCTG-3'; a 499 bp hosszúságú „BS-probe” (plasmid backbone sequence) fragmentnél: 5'CTCTGACTTGAGCGTCGATT-3', 5'-CCCTTTAGTGAGGGTTAATT-3' és a 1301 bázispáros Mmp9 (mouse matrix metallopeptidase 9, NM_013599) DNS szakasznál (amit reakció kontrollnak használtunk): 5'-GGATCCCCAGAGCGTCATTC-3'， 5'-GTCCACCTTGTTCACCTCATTTTG-3'. A keletkező PCR termékeket 1\%-os agaróz-TBE (TRIS borate EDTA) gélen választottuk el 200 ng GeneRuler ${ }^{\mathrm{TM}}$ 100bp DNA Ladder (Fermentas SM0242) molekulaméret jelzőoldat mellett.

A Southern hibridizációhoz a genomikus DNS mintákat először részlegesen EcoRI vagy BamHI endonukleázzal kezeltük. Továbbiakban a kezelt mintákat $0.8 \%$-os agaróz-TBE gélen elválasztottuk és egy éjszakán keresztül alkalikus közegben Hybond N+ (Amersham RPN303B) membránra kötöttük, majd a membránt 1 órán át $80{ }^{\circ} \mathrm{C}$-on hökezeltük. $\left[{ }^{32} \mathrm{P}\right] \mathrm{dCTP}$ jelölt, transz- 
gén specifikus próbákat a Rediprime II Random Prime Labeling System (Amersham RPN1633) alkalmazásával készítettük el 1\%-os agaróz-TBE gélen tisztított hrGFP PCR termékből (lásd fent). A próbát a membránra kötött genomikus DNS darabokra hibridizáltuk, majd a radioaktív jelet 4 napon keresztül $-80{ }^{\circ} \mathrm{C}$-on Agfa X-ray filmen fogtuk fel. A módszer részleteit tekintve a korábbiakban leírtak szerint jártunk el (62).

\section{Fluoreszcens in situ hibridizáció (FISH)}

P3CG heterozigóta egerek lépéből limfocitákat gyüjtöttünk, majd ezeket a sejteket 3 napon keresztül $\mathrm{RPMI}+5 \mu \mathrm{g} / \mathrm{ml}$ Concanavalin-A tartalmú tápoldatban $37{ }^{\circ} \mathrm{C}$-on $5 \mathrm{v} / \mathrm{v} \%$-os $\mathrm{CO}_{2}$ koncentráció mellett tartottuk. Ezek után mitózisban leállítottuk a sejtciklust 5 órás $5 \mu \mathrm{g} / \mathrm{ml}$ kolhicin kezeléssel. A sejtszuszpenziót PBS (phosphate buffered saline) oldatban mostuk és $75 \mathrm{mM}$ $\mathrm{KCl}$ oldatban szuszpendáltuk újra és ebben tartottuk 5 percig. A sejteket ezután metanol:ecetsav 3:1 térfogat arányú, $-20^{\circ} \mathrm{C}$-os keverékével fixáltuk és $500 \mathrm{~g}$-vel 10 percig centrifugáltuk. A fixálót háromszor cseréltük a sejteken, majd a fixált szuszpenzióból üveg tárgylemezre cseppentettünk belölük. A kicseppentett szuszpenziót fixálóval leöblítettük és sürített levegővel 3 percig szárítottuk. A kromoszóma készítményeket további felhasználásig (legfeljebb 1-2 napig) sötét dobozban szobahőmérsékleten tároltuk. Hibridizációs próbának a teljes pPUR plazmidot (Clontech 631601) használtuk, amelyet Biotin Nick Translation Mix (Roche 11745824910) alkalmazásával biotinnal jelöltünk meg. A plazmid azért volt alkalmas a P3CG jelenlétének igazolására, mert tartalmazza a transzgénben is jelenlevő, arra specifikus SV40 poliadenilációs jel szekvenciáját, de az egér genommal komplementer DNS szakaszt nem. A kromoszóma preparátumokat 1 órán keresztül RNáz A enzimmel kezeltük $37^{\circ} \mathrm{C}$-on, felszálló etanolsorban víztelenítettük, két percig formamiddal $75^{\circ} \mathrm{C}$-on denaturáltuk, leszálló etanolsorral rehidráltuk, majd 12 órán át $37^{\circ} \mathrm{C}$-on a biotin jelölt próbával hibridizáltuk. Mosás után a lekötődött próbát fluoreszcein konjugált avidin D (Vector A-2011) és biotinilált anti-avidin D (Vector BA-0300) ellenanya- 
gokkal jelöltük meg 3 lépcsőben (fluoreszcein-avidin - biotinilált anti-avidin - fluoreszceinavidin). A kromoszómákat DAPI (4',6-diamidino-2-fenilindol) tartalmú beágyazó oldattal (Vector H-1200) fedtük le. A mikroszkópos képeket Zeiss AxioImager.Z1 fluoreszcens mikroszkópon 1000x immerziós nagyítással EC Plan-Apochromat 100x/1.4 Oil (Zeiss 420792-9900) objektívvel és 49-es jelü kék (Zeiss 488049-0000) valamint 38 HE jelü zöld (Zeiss 488038-0000) szürőkkel készítettük és Zeiss Axiovision 4.6 szoftverrel dolgoztuk fel. Részleteit tekintve a transzgén kimutatásához felhasznált FISH eljárást egy szakirodalomban is közölt protokoll szerint végeztük el (64).

\section{RNS tisztítás és minőségellenőrzés}

Frissen - az állatok kíméletes megölése után 30 percen belül - a vizsgált szervekből kb. 50-50 mg tömegü darabot különítettünk el RNS tisztításhoz és fagyasztottunk le azonnal folyékony nitrogénben. Ebben két hétnél tovább nem tároltuk a szervmintákat. Az egész szervdarabokból RNAzol-RT (Molecular Research Center RN190) reagenssel a mellékelt útmutatónak megfelelöen teljes RNS frakciót tisztítottunk. A tisztítás végén képződő RNS csapadékokat RNáz mentes vízben oldottuk fel és legfeljebb 3 napig tároltuk $-80{ }^{\circ} \mathrm{C}$-on ebben a formában. Az RNS minták abszorbancia értékekeit 230, 260 és 280 nm hullámhosszon, illetve az ezekből történő koncentráció számítást NanoDrop ND-1000 Spectrophotometerrel végeztük. $\mathrm{A}_{260} / \mathrm{A}_{280}$ abszorbancia arányok értéke minden minta esetében $2.0 \pm 0.04$ tartományba esett. Az RNS mintáink épségét egy előzőleg leírt módon denaturáló elektroforézissel 1,2\%-os agaróz-TAE (TRIS accetate EDTA) gélen ellenőriztük (65). Csak azokat a mintákat használtuk fel a további kísérleteinkhez, amelyeknél a 18S és $28 \mathrm{~S}$ riboszómális RNS sávok tisztán láthatóak voltak jelentős mértékű alacsony molekulatömegü elkenődés nélkül. Mintánként 7,5 $\mu \mathrm{g}$ teljes RNS-t RQ1 RNase-Free DNase (Promega M6101) enzimmel kezeltünk 10 percen át $37^{\circ} \mathrm{C}$-on, hogy az esetlegesen hátramaradt genomikus DNS szennyezéstől megszabaduljunk. Az RNS mintákat templátként használtuk a 
cDNS (komplementer DNS) szintézishez, amelyet a Fermentas RevertAid H- kittel (Fermentas K1632) és a mellékelt oligodT primerrel végeztünk. Az eljárást a teljes RNS mennyiséggel kezdtük, majd az enzim hozzáadása előtt a reakciókeveréket egy 2,5 $\mu \mathrm{g}$ (RT-) és egy $5 \mu \mathrm{g}$ RNS-t tartalmazó frakcióra osztottuk szét. Az $5 \mu \mathrm{g}$-os frakcióhoz adtuk a reverz transzkriptáz enzimet $(\mathrm{RT}+)$ és a mellékelt útmutató szerint így $20 \mu$ végtérfogatban szintetizáltuk a cDNS mintákat. Mind az RNS (RT-) és cDNS (RT+) frakciókat 1:5 hígítás után használtuk fel az RT-PCR-hez (reverz transzkripcióhoz kapcsolt PCR) valamint RT-qPCR-hez (reverz transzkripcióhoz kapcsolt kvantitatív valósidejü PCR).

\section{Reverz transzkripcióhoz kapcsolt valósidejü kvantitatív PCR (RT-qPCR)}

Az összes RT-qPCR technikát érintő kísérletet a közelmúltban megjelent összefoglaló közlemény útmutatásainak figyelembe vételével terveztünk és kiviteleztünk (66). A kvantitatív valósidejü PCR-eket Bio-Rad CFX96 rendszeren hajtottuk végre $20 \mu$ l-es reakció-térfogatban. Ez $10 \mu 1$ iQ ${ }^{\mathrm{TM}}$ SYBR ${ }^{\circledR}$ Green Supermixet (Bio-Rad 170-8882) és $4 \mu$ l templátot tartalmazott. 4-4 picomol (jobbára RTPrimerDB azonosító számmal (ID) is rendelkező (67)) primert adtuk a reakcióhoz, hogy a Polr2a (ID:1487): 5'-GACAAAACTGGCTCCTCTGC-3'， 5'-GCTTGCCCTCTACATTCTGC-3'; egér CCNC 1 izoforma (ID:8213): 5'-TGCCGAAACCAAAACCACCTCCA-3', 5'-GGTCCACTACGGGATTCTTCAGGGT-3'; egér CCNC 2 izoforma (ID:8227): 5'-ATGCCGAAACCAAAACCACCTC-3'， 5'-TTGCCTTATCTTGTCCAGCATCATCTT-3' valamint hrGFP: 5'-ACCCCGAGGACATCAGCGACTT-3', 5'-TGGGGAAGTTGCGGCCCTTGTA-3' átírt géntermékeket felsokszorozzunk. Mindegyik reakcióhoz a következő programot használtuk: $95^{\circ} \mathrm{C}, 3$ perc; $40 \mathrm{x}\left(95^{\circ} \mathrm{C}, 15\right.$ másodperc és $60^{\circ} \mathrm{C}, 30$ másodperc $) ; 95^{\circ} \mathrm{C}, 10$ másodperc, illetve 5 másodperc hosszúságú ,olvadási görbe” lépések $60{ }^{\circ} \mathrm{C}$-tól $95{ }^{\circ} \mathrm{C}$-ig $0.5{ }^{\circ} \mathrm{C}$-kal növelve. Minden primerpár esetében a képződő PCR termék egy csúcsú „olvadási görbét” eredményezett és agaróz gélelektroforézis után megfelelő méretünek mutatkozott. Egy-egy primerpárhoz tartozó 
PCR terméket CloneJET PCR Cloning kittel (Fermentas K1232) a mellékelt pJET1.2 vektorba építettük és T7 primerrel kapilláris szekvenáltuk, amely igazolta, hogy minden reakcióban specifikusan csak a vizsgálni kívánt gén terméke sokszorozódik. Minden egyes szervminta esetében egy RT- kontroll (RNS frakció) és három RT+ (cDNS frakció) technikai ismétlő reakciót állítottunk össze. Egy génexpressziós érték kiszámolásához M. Pfaffl módszerét használtuk (68), amelyhez három különböző egyedből (biológiai ismétlés) származó szervmintában mért értéket átlagait vettük alapul. Minden hírvivő RNS transzkripciós szintet a Polr2a (RNS polimeráz II, polipeptid A) RNS expressziójához normalizáltunk, amely viszonylag állandónak tekinthető a különböző egér szervekben, illetve szövetekben (69). Az adatokat a Bio-Rad CFXManager 2.0 szoftverrel gyüjtöttük össze és dolgoztuk fel.

\section{Reverz transzkripcióhoz kapcsolt PCR (RT-PCR)}

A $25 \mu$ l-es RT-PCR reakciókhoz 250 ng RNS-nek megfelelő RT- (RNS) és RT+ (cDNS) templát oldatokat, a genotipizáláshoz is használt (lásd fent!), 651 bp méretű terméket adó hrGFP valamint pozitív kontrollnak egy 840 bp hosszúságú $\beta$-actin cDNS fragment amplifikálásához szükséges (5'-CACCACACCTTCTACAATGAGC-3' és 5'-GCCGGACTCATCGTACTCCTGC-3' szekvenciájú) egyenként $10 \mathrm{pmol} / \mu$ töménységű primerpárt adtunk. Ezekhez a reakciókhoz is a GoTaq Flexi DNA Polymerase kitet (Promega M8301) alkalmaztuk. A keletkező DNS darabokat gélelektroforézissel 1\%-os agaróz-TBE gélen választottuk el 200 ng GeneRuler ${ }^{\mathrm{TM}}$ 100bp DNA Ladder (Fermentas SM0242) molekulaméret jelzőoldat mellett.

\section{Szövettani metszetek készítése és vizsgálata}

A szövettani vizsgálatokhoz 2-3 mm átméröjü, frissen kimütött egér szervdarabokat PBS-ben történő öblítés után $4 \%$ formaldehid-PBS oldatban fixáltuk 2 napig $4{ }^{\circ} \mathrm{C}$-on, majd további 3 napig impregnáló oldatban $\left(30 \%\right.$ szacharóz, $\left.2 \mathrm{mM} \mathrm{MgCl}_{2}\right)$ áztattuk $4{ }^{\circ} \mathrm{C}$-on. A mintákat a további- 
akban Tissue-Tek ${ }^{\circledR}$ O.C.T. ${ }^{\text {TM }}$ Compound (Sakura Finetek 4583) folyadékba ágyaztuk és $-80{ }^{\circ} \mathrm{C}$ on fagyasztottuk, illetve tároltuk. A befagyasztott szövetdarabokból Shandon Cryotome FE (Thermo Fisher Scientific) kriosztát készüléken $8 \mu \mathrm{m}$ vastagságú metszeteket készítettünk -20 ${ }^{\circ} \mathrm{C}$-on, amelyeket a mellékelt leírás szerint 3-trietoxiszililpropilaminnal (Sigma A3648) felületkezelt, szobahőmérsékletü tárgylemezre olvasztottunk. A metszeteket azonnal 95 v/v \% etanolban utófixáltuk, majd szobahőmérsékleten száradni hagytuk, végül DAPI (4',6-diamidino2-fenilindol) tartalmú fedő oldattal (Vector H-1200) fedtük le. A mikroszkópos képeket Zeiss AxioImager.Z1 fluoreszcens mikroszkópon összesen 200x optikai nagyítással EC Plan-Neofluar 20x/0.5 Ph2 (420351-9910) objektívvel és 49-es jelü kék (Zeiss 488049-0000) valamint 38 HE jelü zöld (Zeiss 488038-0000) szürőkkel, illetve fáziskontraszt optikával készítettük. A képek további feldolgozásához a Zeiss Axiovision 4.6 szoftvert használtuk.

\section{Immunoblotting}

Az egér szervekből kb. 50 milligrammos darabot vettünk ki (össztérfogat kb. $150 \mu \mathrm{l}$ ) és $1 \mathrm{ml}$ jégben hütött steril PBS-ben mostunk Eppendorf csőben. A mosott szervdarabhoz $150 \mu$ l hideg lízispuffert (20 mM TRIS pH 7,5, $100 \mathrm{mM} \mathrm{NaCl}, 5 \mathrm{mM} \mathrm{MgCl} 2,0,2 \%$ NP40 [vagy Igepal CA630] steril desztillált vízben hígítva) adtunk és kézi, üveg törőpálcával teljesen homogenizáltuk. A sejtmagokat 2500g-vel történő 5 perces centrifugálással leválasztottuk a sejtlizátumból. A felülúszóhoz 1/3 térfogatának megfelelő ( $\mathrm{kb} .100 \mu \mathrm{l})$ mennyiségü 4x töménységü Laemmli puffert (70) adtunk és 5 percig forraltuk, majd jégen lehütöttük. Az eljárás során keletkező fehérje mintákból 5-5 $\mu$ l-t kétrétegü, azaz 4\% felső és 12,5\% alsó rétegü, függőleges SDS-poliakrilamid gélen 1x töménységü TGS elektroforézis pufferben (TRIS-glicin-ㅇDS) 40 mA áramerősséggel elválasztottuk és Coomassie brilliánskékkel festettük JM Walker protokollja szerint (71). Az eredeti fehérjeoldatainkat a festődés erőssége alapján 1x töménységü Laemmli pufferben körülbelül közel azonos töménységüre hígítottuk, két sorozatban vittük fel ugyanarra a gélre és újra elvá- 
lasztottuk a fentebb leírt módszerrel. Az egyik sorozatot ellenőrzésképpen Coomassie brilliánskékkel festettük, míg a másik elválasztott fehérjesorozatot frissen összeállított transzfer pufferben (48 mM TRIS, 39 mM glicin, $20 \mathrm{v} / \mathrm{v} \%$ metanol) 90 percen keresztül $260 \mathrm{~mA}$ áramerősségü elektromos térben PROTRAN BA85 nitrocellulóz membránhoz (Sleicher \& Schuell 401196) kötöttük. A gélelektroforézis és elektroblotting munkafázisokhoz OmniPage Mini (Cleaver Scientific VS10) rendszert használtunk. A fehérjét kötött membránt szobahőmérsékleten 1 óráig friss telítő oldatban ( $5 \%$ sovány tejpor PBS-ben), majd $4{ }^{\circ} \mathrm{C}$-on 12 órán át az antigén jelöléshez ( $\beta$-actin-kötő poliklónális IgG: Abcam ab8227; hrGFP-kötő poliklónális IgG: Stratagene 240142) használatos ellenanyag oldatában áztattuk és (3x5 percet) PBS-ben mostuk. Az elsődleges ellenanyagok kimutatásához szobahőmérsékleten 1 órán keresztül áztattuk a membránt tormaperoxidázzal konjugált nyúl IgG-hez kötődő másodlagos ellenanyag (Dako P0399) oldatában. Minden ellenanyagot a telítőben 1:5000 arányban, frissen hígítottunk. Alapos (5x5 perc) PBS mosás után a membránt 5 percen keresztül frissen összeállított Immobilon Western Chemiluminescent HRP Substrate (Millipore WBKL S01 00) oldattal kezeltük. A tormaperoxidáz enzimreakció eredményeképpen képződő fényjelet 2 percen keresztül sötétben Agfa X-ray filmen fogtuk fel és standard eljárással hívtuk elő.

\section{Transzkripciós faktor kötöhely keresés}

CREB1 faktor kötőhely kereséséhez a JASPAR legfrissebb, 2010-es adatbázisát (http://jaspar.genereg.net) és motívumkereső algoritmusát használtuk (72). Forrásszekvenciának az egér ciklin C promóterének TS-től számított első 3397 bázispár hosszúságú szakaszát adtuk meg. A keresőalgoritmust alapbeállításokkal futtattuk le és $80 \%$-ot állítottunk be érzékenységi/pontossági küszöbnek (relative profile score threshold), amivel a keresés találati pontossága határozható meg (73). 


\section{Eredmények}

\section{Az izolált ciklin C promóterdarabok génkifejeződést indukálnak}

A pP3CG elkészítése során számos mutáns plazmid is keletkezett. Ezek közül képződött egy olyan klón is, amely tartalmazta a teljes 3570 bp méretü promóterszakaszt az 5'UTR-rel együtt, de a hrGFP kódoló szekvencia $5^{\prime}$ végéröl törlődött egy 151 bázispárnyi szekvencia (pP3CGdelGFP). Ez egy rövidebb leolvasási keret képződését okozza, amely az eredetileg 239 aminosavból álló hrGFP fehérje C-terminálisának csak az utolsó 119 aminosavát kódolja. Ezt a klónt a továbbiakban hrGFP deléciós kontrollként használtuk. A pP3CG (3,4 kb promóter-5'UTR darabot hordozó), pCChrGFP1 (TS proximális promóter deléciós mutáns), pP3CGdelGFP (negatív kontroll) és phrGFP-1 (pozitív kontroll) plazmid konstrukciók transzfektálását és expressziójának ellenőrzését emberi 293FT vesesejt kultúrákon, azonos kiindulási sejtszámmal és plazmid mennyiséggel végeztük. A sejtekben a hrGFP jelenlétét egységesen mindegyik kultúra esetében 24 és 48 órával a transzfekció után fluoreszcens mikroszkóppal ellenőriztük (6. ábra). Kísérleti eredményeink azt mutatják, hogy míg a TS proximális promóter deléciós mutáns pCChrGFP1 és a kontrollként használt hrGFP deléciós mutáns pP3CGdelGFP plazmidok nem, de a CCNC 3,4 kilobázisos promóterdarabját és az 5' UTR-jét hordozó pP3CG konstrukció és a pozitív kontroll-

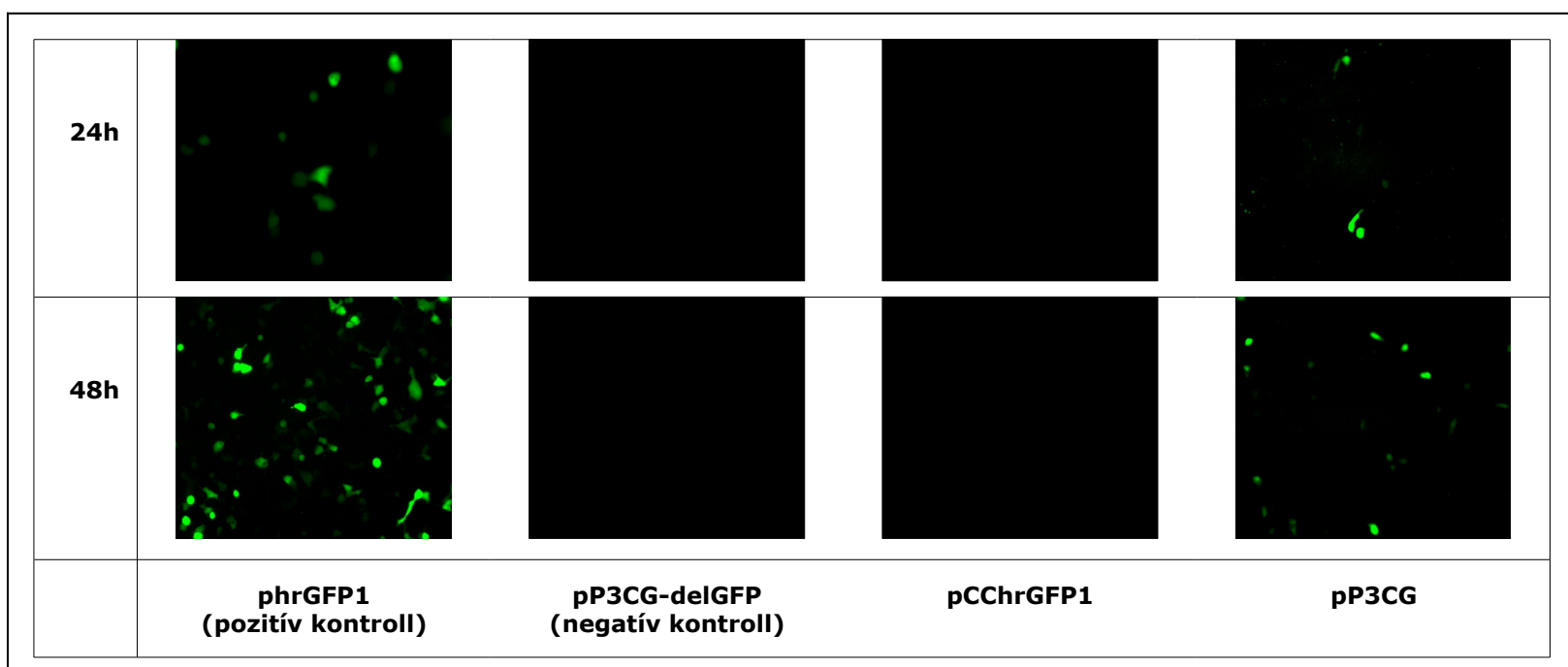

6. ábra: A 293FT humán vesesejtekben észlelhető fluoreszcens jelek 24 és 48 órával a transzfekció után 
ként használt phrGFP-1 vektor már képes fluoreszcens mikroszkóppal is látható hrGFP expressziót indukálni emberi 293FT vesesejtekben. Ezen kísérlet megismétlésekor ugyanezeket az eredményeket kaptuk 20-30\%-kal kisebb sejtszám esetében is.

A pP3CG és az erre alapozott pP10CG plazmid konstrukciókkal megismételtük a tranziens transzfekciókat P19 egér teratokarcinóma sejtvonalon is. Mindkét plazmidnál, a 293FT sejtvonalhoz hasonlóan a pP3CG és pP10CG transzfektáns P19 sejtkultúrákban is megfigyelhető volt a hrGFP jel transzfekció után 24 és 48 óra múlva is. Ezek alapján megállapítható, hogy mind a 3,4, mind a 10,4 kb méretü CCNC promóter (+ 5'UTR) darab képes génexpressziót indukálni emlős sejtekben, míg a ciklin $\mathrm{C}$ promóter első 58 bázispárjának (és az 5'UTR-nek) deléciója a fluoreszcens mikroszkópia kimutatási küszöbe alá csökkenti a jelzőgén kifejeződését.

\section{Az egy lókuszú beépülés élő transzgenikus egereket eredményezett}

Összesen 751 megtermékenyített petesejtbe injektáltuk a P3CG transzgént. Az élő, injektált zigóták álterhes anyákba ültetése után normál idejü terhesség (azaz 18-21 nap) elteltével 34 élö, újszülött egeret kaptunk (további számadatokat az 1. táblázat tartalmazza!). A született $\mathrm{F}_{0}$ generációs egerek

\begin{tabular}{|l|l|}
\hline kinyert zigóta (és éretlen petesejt) & 1242 \\
\hline injektált, ép zigóta & 751 \\
\hline injektálást túlélő zigóta & 445 \\
\hline injektált, beültetésre került zigóta & 434 \\
\hline élő újszülött & 34 \\
\hline ivarérett kort elérő fiatal felnőtt & 29 \\
\hline alapító $\left(F_{0}\right)$ transzgénikus felnőtt & 4 \\
\hline
\end{tabular}

1. táblázat: Egyedszámok a transzgénikus egerek előállításának egyes fázisaiban mindegyikénél megvizsgáltuk a transzgén jelenlétét arra specifikus PCR és Southern hibridizációs technikák segítségével.

A PCR vizsgálatban a primerek tervezésénél olyan DNS szekvenciákat vettünk alapul, amelyek kizárólag az injektált P3CG transzgénben vannak jelen. A hrGFP specifikus PCR esetében a hrGFP kódoló szekvenciájában, míg a BS-probe PCR-nél a transzgén bakteriális (pBluescript SK II+ plazmid, Stratagene 212205) fragmentet tartalmazó végén kerestünk PCR-hez alkalmazható 


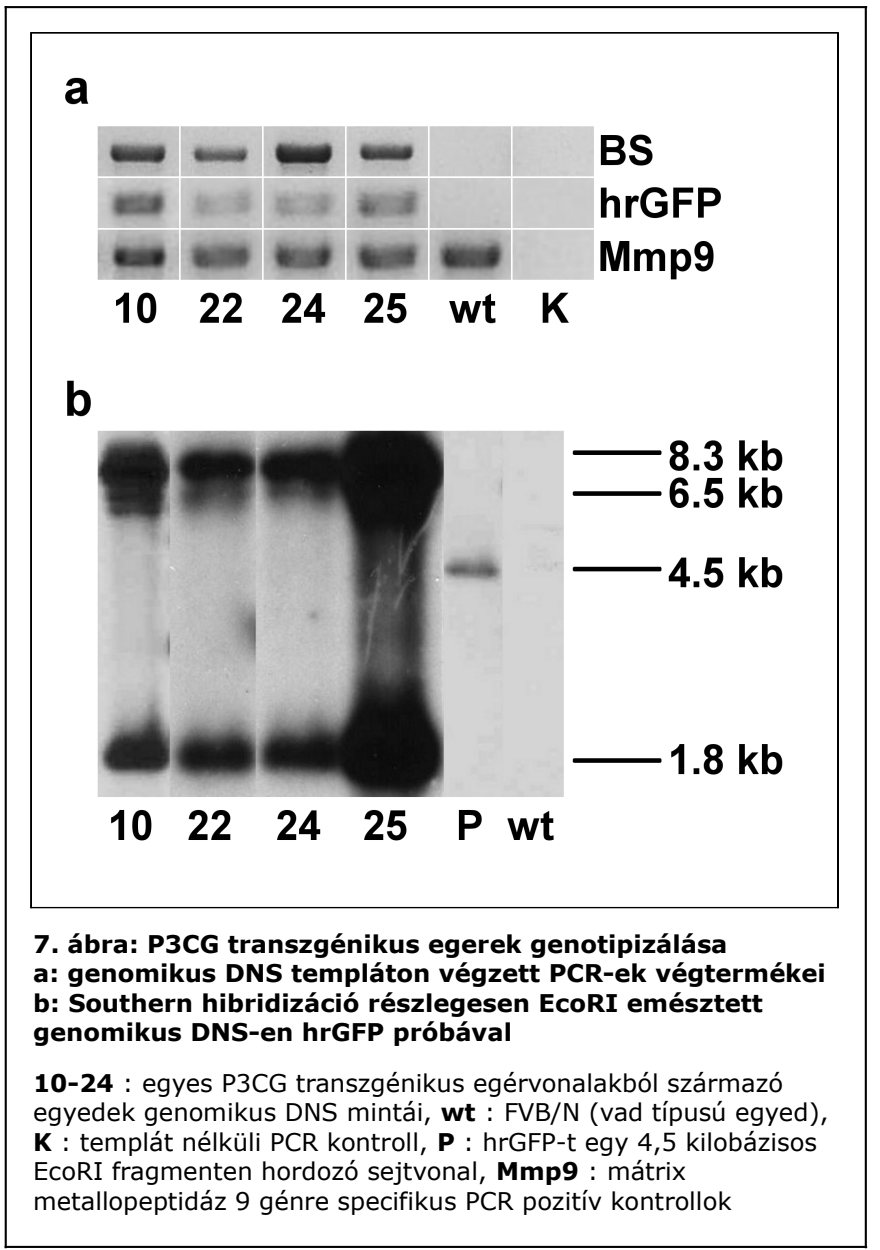

primer párokat szoftver segítségével (5. ábra). Az Ensembl egér genom adatbázisában BLASTN kereséssel (alapbeállításokkal) leellenőriztük a primerszekvenciáink esetleges jelenlétét is (74). A keresés szerint ezekkel az oligonukleotidokkal teljesen komplementer DNS szakaszokat a házi egér referencia genomja nem tartalmaz, tehát felhasználhatónak bizonyultak a transzgenikus fragment kimutatásához.

Az injektálásból származó 34 egérnél 1-2 héttel megszületésük után elvégeztük a hrGFP specifikus PCR-t. Összesen 4 egér, azaz a P3CG10, -22, -24 és -25 jellel ellátott példányok esetében tudtuk amplifikálni a hrGFP fragmentet (7.a ábra). Az amplifikált fragmentumokat egy 404 és egy 247 bp méretü DNS darabot adó PstI restrikciós emésztéssel mindegyik esetben leellenőriztük, amely megerősítette, hogy a transzgént amplifikáltuk. A transzgenikus kimérákat összekereszteztük vad típusú, FVB/N törzsbeli fajtársaikkal. A képződő $\mathrm{F}_{1}$ utódgeneráció mindegyik egyedénél megismételtük a hrGFP PCR-t és ez alapján mind a négy vonalból választottunk egy-egy hrGFP pozitív utódot. Ezen utódok farokból izolált DNS mintáin elvégeztük a BS-probe amplifikálását is (7.a ábra), amely a hrGFP specifikus PCR-rel teljesen megegyező eredményt adott. Ebből arra következtettünk, hogy minden transzgenikus vonalban teljes egészében megtalálható a 3,6 kb hosszúságú CCNC promóter+5'UTR szekvencia a hrGFP leolvasási keretével együtt.

Az alapító $F_{0}$ transzgenikus egerek genomikus DNS-ében a P3CG transzgén jelenlétét Southern 
hibridizációval is kimutattuk (7.b ábra). A vizsgálatot megismételtük még az első, $\mathrm{F}_{1}$ utódgeneráció összes egyedénél is. A vizsgálandó egerek genomikus DNS-ét elöször EcoRI enzimmel emésztettük meg. Ebben a kísérletben is az $\mathrm{F}_{0}$ generációnál csak annak a négy transzgenikus egérnek a DNS mintáiban észleltük a P3CG jelenlétét, amelyekben az PCR-rel is kimutatható volt. Mind a négy transzgenikus vonal esetében a hrGFP próba legtöbbször 1,8 és 8,3 kilobázisos DNS darabokhoz kötődött. A transzgénben EcoRI felismerőhely összesen két helyen, a hrGFP szakasz két oldalán található. A hrGFP próbával komplementer részt tartalmazó DNS fragment teljes EcoRI emésztés esetén minden esetben 1816 bp méretű. Ez elméletileg akkor is igaz kell hogy legyen, ha a fragment a genom bármely lókuszába/lókuszaiba és/vagy bármilyen mennyiségben integrálódik és épen marad. Amennyiben a transzgén EcoRI helyei közül csak az egyiknél történik emésztődés, akkor az integráció helyétől/helyeitől, illetve a beépült transzgenikus fragmentek darabszámától és egymáshoz viszonyított orientációjától függően különböző méretü, de 1,8 kilobázisnál hosszabb szekvenciák képződhetnek. A legvalószínübb az, hogy egyetlen lókuszba többszörös beépülés történt. Ha ez az eset áll fent, akkor a tisztán transzgenikus eredetü DNS fragmentek száma többszöröse a transzgenikus régióval szomszédos egér genomikus részt is tartalmazó DNS fragmentek számának. Ezek miatt a tisztán transzgenikus DNS daraboknál a filmen sokkal erősebb radioaktív jelet láthatunk, mint azoknál a szekvenciáknál, amelyekben a transzgénnel szomszédosan az integráció helyéről származó egér genomikus DNS is van. Ezeket a kísérleteket megismételtük még az egér DNS-ek BamHI emésztése után is. A fentiekkel egybehangzóan csak a transzgenikus egerek DNS mintáinál találtunk radioaktív jelet.

A FISH eredménye azt mutatta, hogy mind a négy transzgenikus egérvonaban 1-1 lókuszba épült be az általunk bevitt P3CG DNS (8. ábra). A metafázisos kromoszóma készítményeken megfigyelhető még az is, hogy az egyes kromoszóma karokon hol helyezkedik el a transzgén. A 

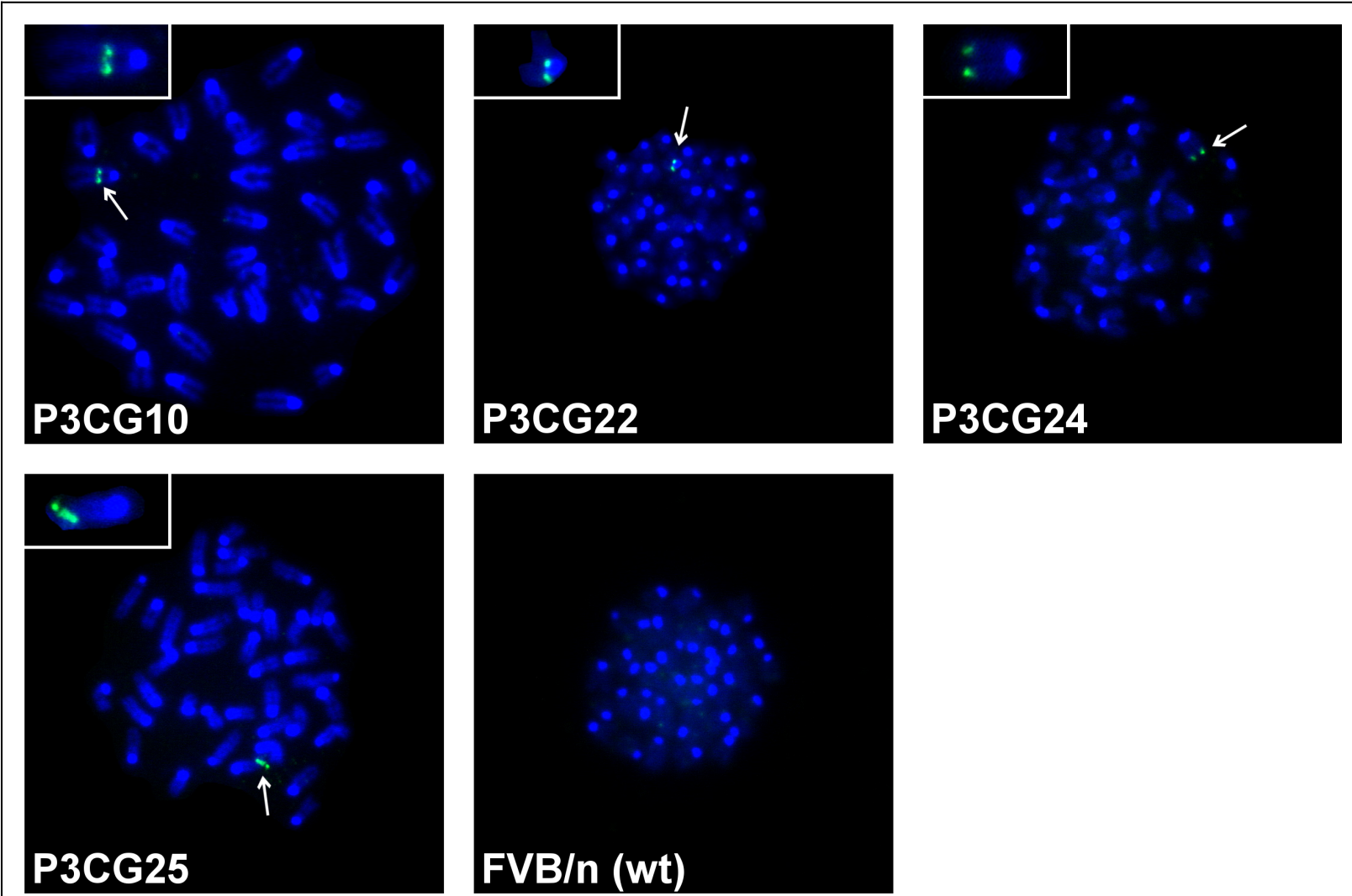

8. ábra: Fluoreszcens in situ hibridizáció SV40 specifikus biotin-jelölt plazmid próbával metafázisban leállított egér lépböl eltávolított fehérvérsejtek kromoszómáin

Kék jel : DAPI festett DNS; zöld jel és nyilak : kromoszómákra letapadt, fluoreszceinnel jelölt próbát mutatják; P3CG10-

P3CG25 : heterozigóta transzgénikus egerek; FVB/n (wt) : vad típusú egér

A képek bal felső sarkaiban a jelölődött kromoszómák nagyítva láthatók.

P3CG10 egereknél kromoszóma kar közepén, P3CG22 egyedeknél szubcentromerikus régióban, P3CG24 és -25 egyedek esetében pedig telomerikusan következett be az integráció. Ezek alapján nagyon valószínü, hogy a mind a négy vonalnál különböző a genomi integrációs hely, azaz a génkifejeződést esetlegesen befolyásoló genomi környezet is.

A P3CG heterozigóta egerek keresztezésével előállított homozigóta vonalak alapítása mind a négy transzgenikus vonal esetében sikerült. A P3CG homozigóta egerek semmilyen feltűnő, látható fenotípusos eltérést nem mutattak a vad típusú $(\mathrm{FVB} / \mathrm{N})$ fajtársaikhoz képest és legalább két generáción keresztül átörökítették a P3CG elemet utódaikba. 


\section{A jelzőgén kifejeződése gyenge és leginkább a herére korlátozódik}

A hrGFP gén hírvivő RNS-ének mennyiségét az összes transzgenikus vonal egy-egy homozigóta hímjének agy (homloklebeny), tüdő (jobb oldali), szív (csúcs), máj (alsó szél),vese (jobb oldali, felső pólus), lép (elülső vége), vastagbél (végbélhez közeli szakasz), here (bal oldal), illetve homozigóta nőstényének petefészek (mindkét oldali) mintáiban RT-qPCR technikával megmértük. Mind a négy P3CG egérvonaban a vizsgált 9 szervdarabból következetesen csak a herében van jelentős génátírás (9. ábra). A P3CG10 vonalnál a here mellett az agyban is észleltünk hrGFP transzkripciót.

Mivel ez a négy vonalból csak egyetlen esetében jelentkezett, így ezt a jelenséget a genomi környezettől függő pozíció effektusnak gondoljuk, jóllehet ez további kísérletes bizonyítást igényel.

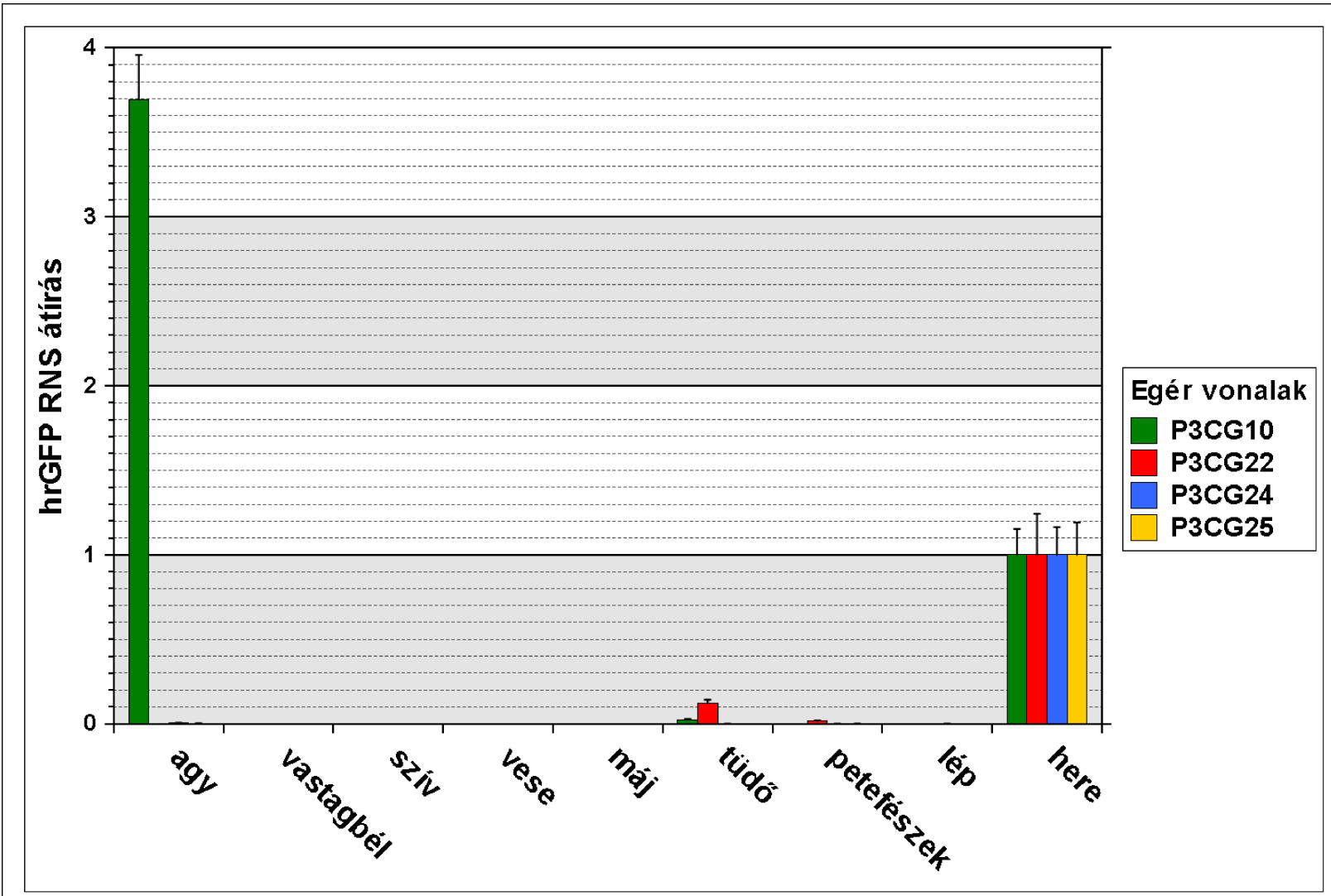

\section{9. ábra: hrGFP specifikus reverz transzkripció kapcsolt kvantitatív PCR}

Az ábrázolt génátírás relatív mértékét a P3CG egerek szervmintáiban három független mérésből számítottuk. Az adatokat a Polr2a (RNS polimeráz II A polipeptid) referencia génhez normalizáltuk. A diagram lineáris léptékű és a herékben mérhető értékek átlagához kalibráltuk. A szórást $\pm 1 \mathrm{SD}$-ben adtuk meg. A hrGFP-re jellemző amplikont nem észleltük az FVB/N egerekből származó szervmintákban, illetve az RT- reakciók esetében (ez utóbbi adatok nincsenek feltüntetve). 


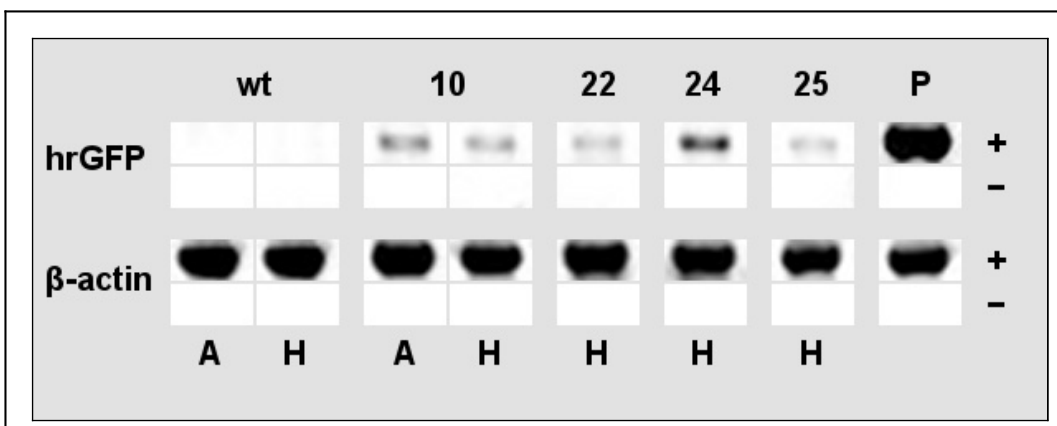

10. ábra: P3CG egerek szervmintáin végzett hrGFP specifikus reverz transzkripció kapcsolt PCR (651 bp méretü) amplikonjai agaróz gélelektroforézissel elválasztva

wt : FVB/N (vad típusú) egér; 10-25 : P3CG10-25 transzgenikus egerek mintái; A oszlopok : agy minták; H oszlopok : here minták; P : pozitív (PCR) kontroll;

+ sor : cDNS/plazmid DNS templát; - sor : RT- (RNS) vagy üres kontroll

Mind a négy vonalnál a jól mérhető transzgén átírást mutató szervek cDNS mintáiban ellenőrzésként elvégeztük a genotipizáláshoz is használt PCR segítségével a hosszabb (651 bp), szintén hrGFP specifikus fragment kimutatását. Ez a kísérlet is minden esetben ismételten igazolta a hrGFP RNS-ének jelenlétét az összes transzgenikus vonalnál a herében, illetve a P3CG10 egyedeknél az agyban is (10. ábra).

A P3CG10 vonal egyik homozigóta hímjének agyából (homloklebeny) és bal oldali heréjéből származó szövettani metszeteken a várttal ellentétben nem észleltünk a hrGFP jelenlétére utaló egyedi mintázatot (11. ábra). Enyhe zöld fluoreszcens jelet láttunk a P3CG10, illetve a kontrollként használt $\mathrm{FVB} / \mathrm{N}$ (vad típusú) állatok heréjében is, de a transzgenikus egerekben

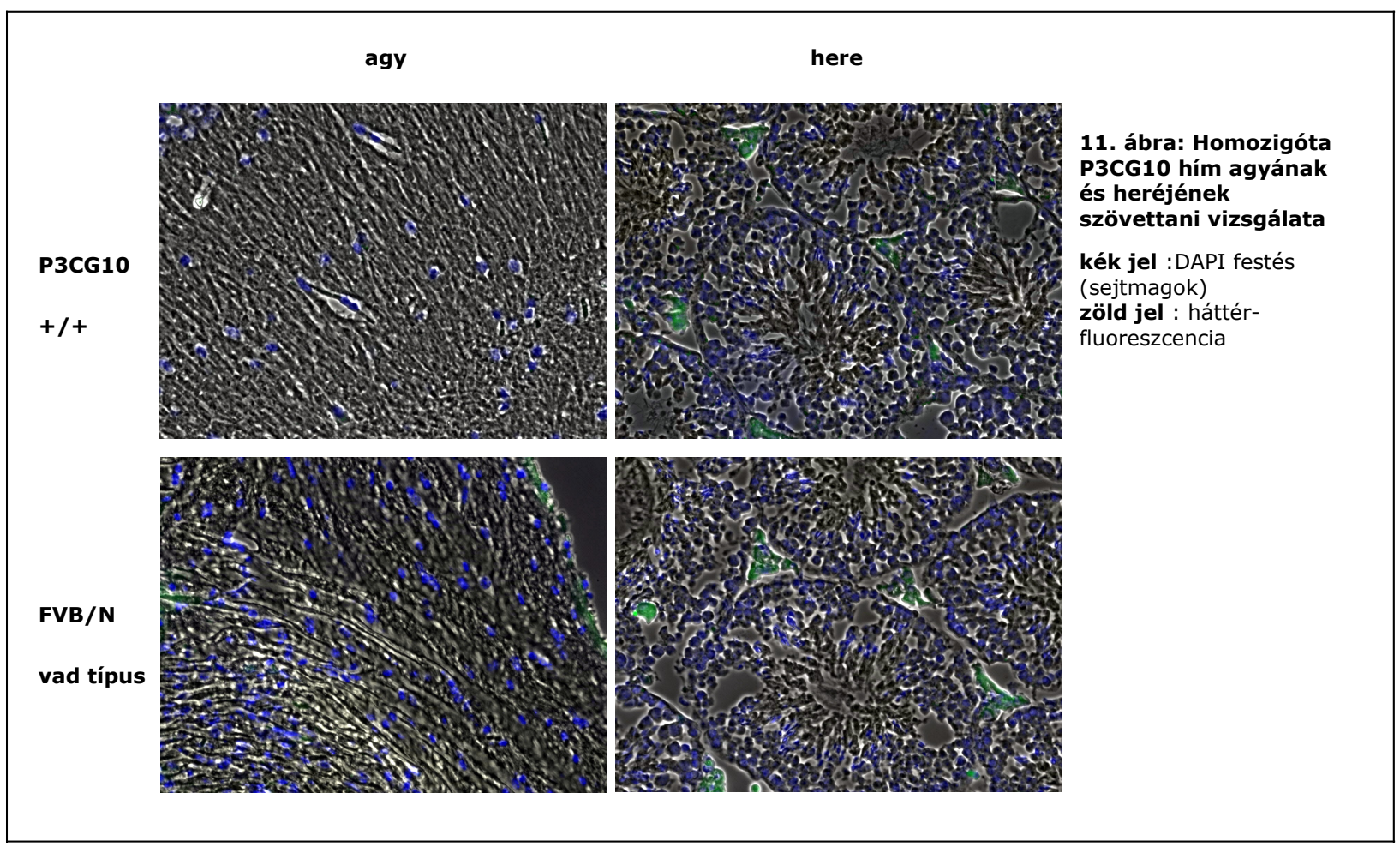


megfigyelhető zöld jel intenzitása, hullámhossza és mintázata nem különbözött jelentősen a vad típusban észlelhetőtől. Mindezekből arra következtettünk, hogy a látott jel nem specifikus háttér-fluoreszcencia. Annak érdekében, hogy ezt a helyzetet tisztázzuk, a kérdéses szervekből fehérjét tisztítottunk és immunoblot

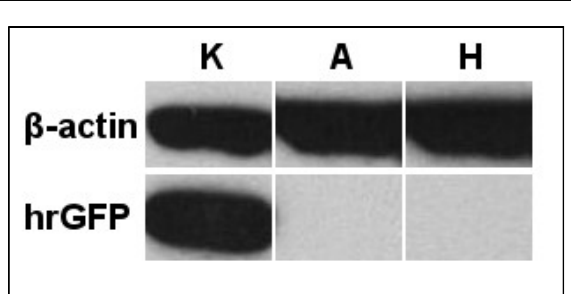

12. ábra: hrGFP immunoblot

K oszlop : hrGFP fehérjét termelő sejtvonal A oszlop : P3CG10 agy H oszlop : P3CG10 here

segítségével próbáltuk meg kimutatni a hrGFP-t. Ennek a kísérletnek az eredményeként nem sikerült észlelni a hrGFP jelenlétét sem az agyban, sem a herében (12. ábra). Ez is azt a feltételezésünket támasztja alá, hogy a hrGFP fehérje vagy nincs jelen ezekben a szervekben vagy olyan kis mennyiségben található meg, ami alkalmatlanná teszi a kimutatását ezen technikák segítségével.

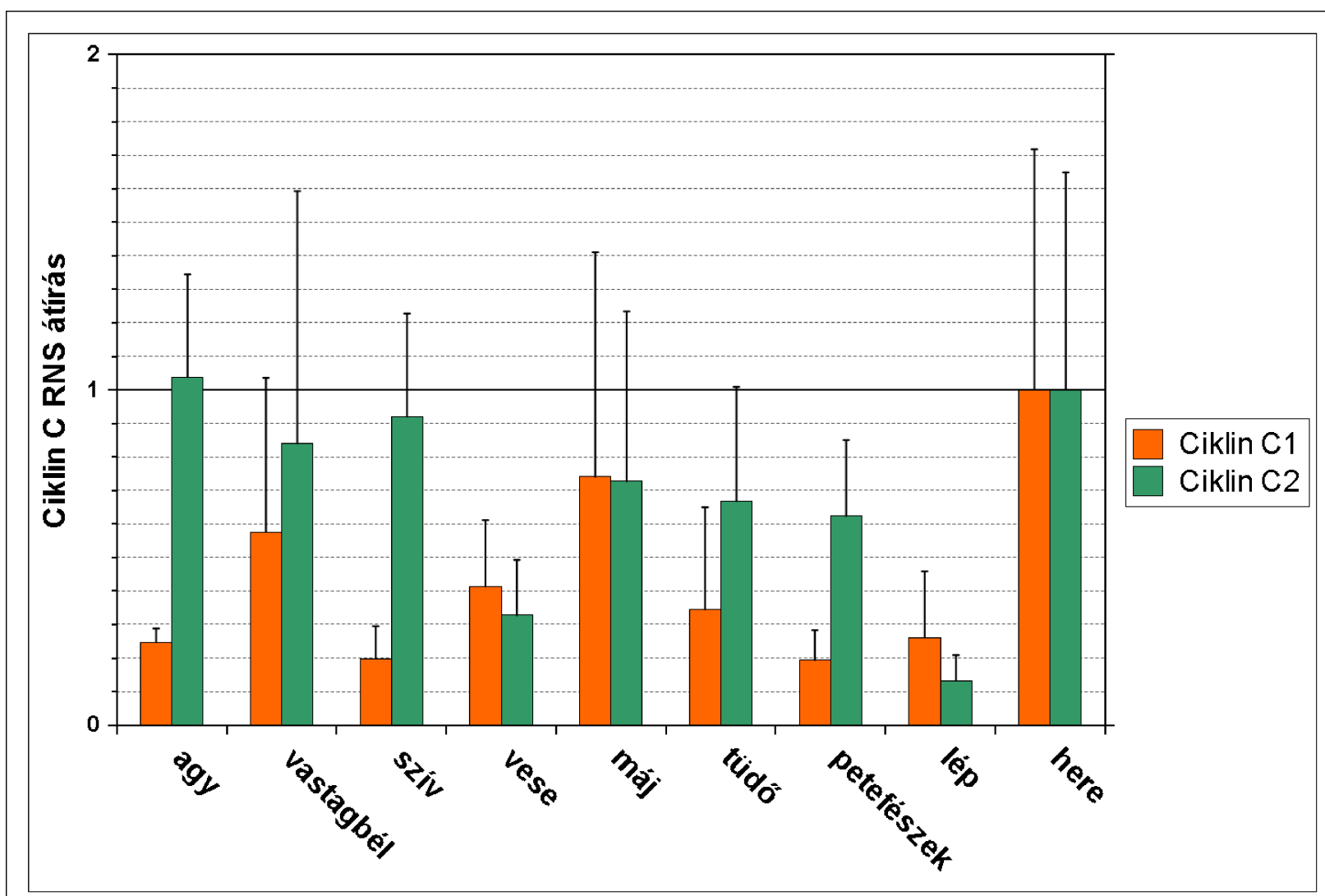

13. ábra: Ciklin C1 és C2 specifikus reverz transzkripció kapcsolt kvantitatív PCR

Az ábrázolt génátírás relatív mértékét három különböző FVB/N (vad típusú) egér szervmintáiból, illetve szervenként három technikai ismétlés alapján számítottuk. Az adatokat a Polr2a (RNS polimeráz II A polipeptid) referencia génhez normalizáltuk. A diagram lineáris léptékű és a herékben mérhető értékek átlagához kalibráltuk. A szórást \pm 1 SD-ben adtuk meg. 


\section{Ciklin C1 és C2 izoformák minden vizsgált szervben megtalálhatók}

A fentebb említett 9 szervmintában megmértük még a két legfőbb ciklin $\mathrm{C}$ izoforma $(\mathrm{C} 1, \mathrm{C} 2)$ hírvivő RNS-ének kifejeződését is FVB/N (vad típusú) egerekben (13. ábra). Kiderült, hogy az endogén ciklin C izoformák RNS-ei változó mennyiségben minden mintában jelen vannak. Az egyes szervekben levő mennyiségi különbségek a kétféle RNS között a tízes számrendszerben mérve egy nagyságrendnél nem nagyobbak. A C1 és C2 izoforma közötti expressziós különbségek az agyban és a szívben a legnagyobbak. Mindkét RNS variánsnál a herében egységesen jelentős génkifejeződést tapasztaltunk.

\section{CRE motívumok az egér ciklin C promóterben}

A transzkripciós faktor kötőhely keresésének eredményeképpen az egér ciklin $\mathrm{C}$ gén promóterének első 3397 bázispár hosszúságú szakaszán 3 feltételezett CRE motívumot találtunk a JASPAR szoftver segítségével a TS-től számított $-3155--3148,-2882--2875$ valamint a $-445--438$ nukleotid régiókban. 


\section{6. Értékelés}

Munkánk során fő célul azt tűztük ki, hogy a ciklin C génexpressziós szabályozásáról újabb információkat szerezzünk emlős modellben. Ehhez a házi egér (Mus musculus) ciklin C promóterét érintő kísérleteket végeztünk in vitro és in vivo élő rendszerekben.

Megállapítottuk azt, hogy a ciklin C transzlációs startpontjától 5' irányban elhelyezkedő 3,6 valamint 10,6 kilobázis méretű DNS szakaszok képesek 293FT emberi vese eredetű és P19 egér teratokarcinóma sejtekben génexpressziót indukálni, tehát elviekben felhasználhatóknak találtuk azokat arra, hogy egy jelzőgén (hrGFP) segítségével követhessük a ciklin C génexpressziós szabályozását. Bebizonyítottuk azt is, hogy a promóter első 58 bázispáros darabjának, illetve az első intronnak a jelenléte létfontosságú a ciklin C génátíráshoz, hiszen ennek hiányában nem tapasztaltunk mérhető génkifejeződést. Leginkább a proximális promóterszakasz deléciója állhat ennek a jelenségnek a hátterében, mert azt feltételezzük, hogy az RNS polimeráz II kötőhelyét tartalmazza ez a régió. Kevésbé valószínű, hogy önmagában az első intron hiánya okozná a génkifejeződés ekkora csökkenését, de ezt kísérletesen nem vizsgáltuk.

Eredeti törekvésünk arra irányult, hogy egérmodellben egy jelzőgénnel egyszerüen tudjuk követni a ciklin C sejt, illetve szöveti szintü génkifejeződését. Ennek érdekében az előzetesen sejtkultúrákban is kipróbált 3,4 kb hosszúságú ciklin C promóterdarabot és 5'UTR-t egyszerre tartalmazó jelzőgén konstrukcióval, azaz a P3CG-vel négy különböző homozigóta transzgenikus egérvonalat állítottunk elö. A transzgenikus egerek 9 különböző szervmintájának vizsgálata során kiderült, hogy a jelzőgén hírvivő RNS-ének átírása megtörténik, de ez leginkább csak a herére korlátozódik. Ezzel szemben a ciklin C1 és C2 izoformák RNS expressziója kimutatható az összes általunk vizsgált szervdarabban, csakúgy, mint a felnőtt emberek szervmintáiban (56). További kísérleteinkkel bemutattuk, hogy a jelzőgénről - feltehetően - nagyon kevés zöld fluoreszcens jel- 
zőfehérje képződik, ha keletkezik egyáltalán. Az a tény, hogy a hrGFP expressziója a P3CG egerekben leginkább csak a herére korlátozódik, azt sugallja, hogy a ciklin C térbeli expressziós szabályozásában az izolált promóterszakaszon kívül más komponensek (távolabbi promóter vagy a CCNC gén nem kódoló részeiben, illetve 3' irányban található elemek) is részt vesznek. Következésképpen az általunk használt jelzőgén rendszer a gyenge jel és az endogén CCNC izoformáktól eltérő expressziós mintázat miatt nem használható fel a ciklin $\mathrm{C}$ jelenlétének tér- és időbeli követésére.

A hrGFP expresszió következetesen, minden vizsgált hím P3CG egér heréjében megfigyelhető volt. A jelzőgén konstrukció minden transzgenikus egérvonal esetében különböző genomi régiókba és csak egyetlen helyre épült be. Ezekböl az adatokból együttesen arra következtettünk, hogy a herében megfigyelhető hrGFP RNS-ének átírása a genomi környezet másodlagos hatásaitól jobbára függetlenül zajlik. Ebből kifolyólag a P3CG-ben használt promóterdarabon olyan eddig ismeretlen faktorok hatásait is vizsgálni lehet in vivo, amelyek ezen keresztül szabályoznak. Továbbá, alkalmazható lehet olyan területeken, ahol megbízható génkifejeződésre van szükség a herében, illetve a herére jellemző génexpressziót szabályozó DNS motívumok keresésénél egy újabb alternatívát jelenthet a már bizonyítottan leginkább here specifikus génexpressziót biztosító promóter elemek mellett (75-79). Emberi és egér herékben is az endogén ciklin C1 és C2 izoformák RNS-e nagyobb mennyiségben van jelen a legtöbb vizsgált szervhez viszonyítva (56). Ezen túlmenően az emberi ciklin C gén promóterének első 3 kilobázisnyi szakaszán azonosítottak négy müködő CRE-t is (60). A mi vizsgálatainkból is kiderült, hogy az egér CCNC promóterének első 3,4 kilobázisnyi szekvenciája is tartalmaz CRE szekvenciákat. A here specifikus génátírást mutató promóterekről leírták, hogy a többi promóterhez képest több CRE helyet tartalmaznak (80). Könnyen elképzelhető, hogy a ciklin C génexpressziójának fenntartásához a herében ez a transzkripciós faktor jelentősen hozzájárul. Ezen kísérleti eredmények együttesen to- 
vább hangsúlyozzák a ciklin C-nek a herére jellemző, eddig még ismeretlen szerepét. 


\section{Köszönetnyilvánítás}

Legelőször szeretném külön köszönetemet kifejezni témavezetőmnek, Dr. Katona Róbertnek, hogy vállalkozott arra, hogy az elmúlt évek során lelkiismeretes, precíz és segítőkész mentorom legyen a molekuláris biológiai kutatómunkában. Nagyon sokat tanultam tőle. Mindig számíthattam rá és a széleskörü tudására szakmai és nem szakmai kérdésekben egyaránt.

Köszönet illeti Prof. Dr. Hadlaczky Gyulát és Prof. Dr. Udvardy Andort, hogy munkámat támogatta, figyelemmel kísérte és jobbító kritikáival, tanácsaival ellátott. Hálával tartozom még Dr. Sinkó Ildikó kolléganőmnek, akinek embriológiával és egerekkel kapcsolatos tudásából és tapasztalatából nagyot meríthettem valamint jelenlegi és volt munkatársaimnak, Dr. Cserpán Imrének, Dr. Csonka Erikának, Dr. Fodor Katalinnak, Dr. Praznovszky Tündének, Dr. Tubak Vilmosnak, Ékes Csabának és Tóth Annának, hogy mindig a segítségemre voltak, ha tanácsra, információra, reagensre vagy valamilyen eszközre volt szükségem és ha elakadtam valamiben. Hálás vagyok a csoport többi tagjának, Horváth Csillának, Katonáné SzékelySzücs Kingának, Kereső Juditnak, Mózesné Holló Gyöngyinek, Odrovics Balázsnak és Rózsavölgyi Mártának is, hogy segítettek a kísérletek kivitelezésénél valamint Deák Mária, Kasza György, Kovács Tímea, Márfai József, Veres Erika és az állatházi dolgozók munkájáért, amivel lehetővé tették, hogy a kutatómunkára összpontosíthassak.

Szeretném még itt megköszönni Prof. Dr. Raskó Istvánnak és kutatócsoportjának, hogy egyetemi hallgatóként és újonc doktoranduszként közelebbröl is megismerkedhettem a tudományos kutatómunkával.

Hálás vagyok még Dr. Czibula Ágnesnek, Dr. Hegedüs Zoltánnak, Dr. Lipinszki Zoltánnak, Dr. Márkus Róbertnek, Dr. Monostori Évának és kutatócsoportjának, Dr. Nagy Istvánnak, Dr. Sepp Róbertnek, Dr. Vizler Csabának, Winter Zoltánnak és Zsámboki Jánosnak az 
együttmüködéseikért valamint az MTA SZBK Genetikai Intézet valamennyi dolgozójának, hogy a szakmai fejlődést támogató közegben dolgozhattam.

Utoljára, de nem utolsósorban köszönet illeti meg szüleimet és testvéremet, akikre életem minden területén támaszkodhattam és közvetett vagy közvetlen segítségükkel is nagyban segítették szakmai előrehaladásomat.

Hálás vagyok még a nyílt forráskódú szoftveres közösség fejlesztőinek és tagjainak is, hogy munkám során nem kellett anyagi forrásokat áldoznom értékes operációs rendszerre (Ubuntu Linux), irodai (OpenOffice.org, LibreOffice) és grafikai programokra (GIMP), hanem azokat szabadon és jogtisztán letölthettem és felhasználhattam. 


\section{Irodalomjegyzék}

1. Demetrick DJ, Matsumoto S, Hannon GJ, Okamoto K, Xiong Y, Zhang H, et al. Chromosomal mapping of the genes for the human cell cycle proteins cyclin $\mathrm{C}(\mathrm{CCNC})$, cyclin E (CCNE), p21 (CDKN1) and KAP (CDKN3). Cytogenet. Cell Genet. 1995;69(34):190-192.

2. Li H, Lahti JM, Valentine M, Saito M, Reed SI, Look AT, et al. Molecular cloning and chromosomal localization of the human cyclin $\mathrm{C}$ (CCNC) and cyclin $\mathrm{E}$ (CCNE) genes: deletion of the CCNC gene in human tumors. Genomics. 1996 Mar 1;32(2):253-259.

3. Li H, Lahti JM, Kidd VJ. Alternatively spliced cyclin C mRNA is widely expressed, cell cycle regulated, and encodes a truncated cyclin box. Oncogene. 1996 Aug 15;13(4):705712 .

4. Hoeppner S, Baumli S, Cramer P. Structure of the mediator subunit cyclin C and its implications for CDK8 function. J. Mol. Biol. 2005 Jul 29;350(5):833-842.

5. Cooper KF, Strich R. Functional analysis of the Ume3p/ Srb11p-RNA polymerase II holoenzyme interaction. Gene Expr. 1999;8(1):43-57.

6. Léopold P, O'Farrell PH. An evolutionarily conserved cyclin homolog from Drosophila rescues yeast deficient in G1 cyclins. Cell. 1991 Sep 20;66(6):1207-1216.

7. Katona R, Lahti JM. Cyclin C [Internet]. UCSD-Nature Molecule Pages. 2006 Feb 28;Available from: http://dx.doi.org/10.1038/mp.a000720.01

8. Lew DJ, Dulić V, Reed SI. Isolation of three novel human cyclins by rescue of G1 cyclin (Cln) function in yeast. Cell. 1991 Sep 20;66(6):1197-1206.

9. Rickert P, Seghezzi W, Shanahan F, Cho H, Lees E. Cyclin C/CDK8 is a novel CTD kinase associated with RNA polymerase II. Oncogene. 1996 Jun 20;12(12):2631-2640.

10. Liu ZJ, Ueda T, Miyazaki T, Tanaka N, Mine S, Tanaka Y, et al. A critical role for cyclin C in promotion of the hematopoietic cell cycle by cooperation with c-Myc. Mol. Cell. Biol. 1998 Jun;18(6):3445-3454.

11. Ren S, Rollins BJ. Cyclin C/cdk3 promotes Rb-dependent G0 exit. Cell. 2004 Apr $16 ; 117(2): 239-251$.

12. Sage J. Cyclin C makes an entry into the cell cycle. Dev. Cell. 2004 May;6(5):607-608.

13. Miyata Y, Liu Y, Jankovic V, Sashida G, Lee JM, Shieh J-H, et al. Cyclin C regulates human hematopoietic stem/progenitor cell quiescence. Stem Cells. 2010 Feb;28(2):308317.

14. Schwartz EI, Smilenov LB, Price MA, Osredkar T, Baker RA, Ghosh S, et al. Cell cycle 
activation in postmitotic neurons is essential for DNA repair. Cell Cycle. 2007 Feb $1 ; 6(3): 318-329$.

15. Rao HV, Thirumangalakudi L, Grammas P. Cyclin C and cyclin dependent kinases 1,2 and 3 in thrombin-induced neuronal cell cycle progression and apoptosis. Neurosci. Lett. 2009 Feb 6;450(3):347-350.

16. Tomashevski A, Webster DR, Grammas P, Gorospe M, Kruman II. Cyclin-C-dependent cell-cycle entry is required for activation of non-homologous end joining DNA repair in postmitotic neurons. Cell Death Differ. 2010 Jul;17(7):1189-1198.

17. Saxena UH, Powell CMH, Fecko JK, Cacioppo R, Chou HS, Cooper GM, et al. Phosphorylation by cyclin C/cyclin-dependent kinase 2 following mitogenic stimulation of murine fibroblasts inhibits transcriptional activity of LSF during G1 progression. Mol. Cell. Biol. 2009 May;29(9):2335-2345.

18. Ye X, Zhu C, Harper JW. A premature-termination mutation in the Mus musculus cyclindependent kinase 3 gene. Proc. Natl. Acad. Sci. U.S.A. 2001 Feb 13;98(4):1682-1686.

19. Hansen U, Owens L, Saxena UH. Transcription factors LSF and E2Fs: tandem cyclists driving G0 to S? Cell Cycle. 2009 Jul 15;8(14):2146-2151.

20. Ohata N, Ito S, Yoshida A, Kunisada T, Numoto K, Jitsumori Y, et al. Highly frequent allelic loss of chromosome 6q16-23 in osteosarcoma: involvement of cyclin $\mathrm{C}$ in osteosarcoma. Int. J. Mol. Med. 2006 Dec;18(6):1153-1158.

21. Galamb O, Sipos F, Molnar B, Szoke D, Spisak S, Tulassay Z. Evaluation of malignant and benign gastric biopsy specimens by mRNA expression profile and multivariate statistical methods. Cytometry B Clin Cytom. 2007 Sep;72(5):299-309.

22. Liu L-X, Liu Z-H, Jiang H-C, Zhang W-H, Qi S-Y, Hu J, et al. Gene expression profiles of hepatoma cell line HLE. World J. Gastroenterol. 2003 Apr;9(4):683-687.

23. Liu L-X, Jiang H-C, Liu Z-H, Zhu A-L, Zhou J, Zhang W-H, et al. Gene expression profiles of hepatoma cell line BEL-7402. Hepatogastroenterology. 2003 Oct;50(53):1496-1501.

24. Morris EJ, Ji J-Y, Yang F, Di Stefano L, Herr A, Moon N-S, et al. E2F1 represses betacatenin transcription and is antagonized by both pRB and CDK8. Nature. 2008 Sep $25 ; 455(7212): 552-556$.

25. Firestein R, Bass AJ, Kim SY, Dunn IF, Silver SJ, Guney I, et al. CDK8 is a colorectal cancer oncogene that regulates beta-catenin activity. Nature. 2008 Sep 25;455(7212):547551.

26. Firestein R, Shima K, Nosho K, Irahara N, Baba Y, Bojarski E, et al. CDK8 expression in 470 colorectal cancers in relation to beta-catenin activation, other molecular alterations and patient survival. Int. J. Cancer. 2010 Jun 15;126(12):2863-2873.

27. Tassan JP, Jaquenoud M, Léopold P, Schultz SJ, Nigg EA. Identification of human cyclindependent kinase 8, a putative protein kinase partner for cyclin C. Proc. Natl. Acad. Sci. 
U.S.A. 1995 Sep 12;92(19):8871-8875.

28. Barette C, Jariel-Encontre I, Piechaczyk M, Piette J. Human cyclin C protein is stabilized by its associated kinase cdk8, independently of its catalytic activity. Oncogene. $2001 \mathrm{Feb}$ $1 ; 20(5): 551-562$.

29. Leclerc V, Léopold P. The cyclin C/Cdk8 kinase. Prog Cell Cycle Res. 1996;2:197-204.

30. Leclerc V, Tassan JP, O'Farrell PH, Nigg EA, Léopold P. Drosophila Cdk8, a kinase partner of cyclin $\mathrm{C}$ that interacts with the large subunit of RNA polymerase II. Mol. Biol. Cell. 1996 Apr;7(4):505-513.

31. Wang G, Cantin GT, Stevens JL, Berk AJ. Characterization of mediator complexes from HeLa cell nuclear extract. Mol. Cell. Biol. 2001 Jul;21(14):4604-4613.

32. Borggrefe T, Davis R, Erdjument-Bromage H, Tempst P, Kornberg RD. A complex of the Srb8, $-9,-10$, and -11 transcriptional regulatory proteins from yeast. J. Biol. Chem. 2002 Nov 15;277(46):44202-44207.

33. Liao SM, Zhang J, Jeffery DA, Koleske AJ, Thompson CM, Chao DM, et al. A kinasecyclin pair in the RNA polymerase II holoenzyme. Nature. 1995 Mar 9;374(6518):193-196.

34. Cadena DL, Dahmus ME. Messenger RNA synthesis in mammalian cells is catalyzed by the phosphorylated form of RNA polymerase II. J. Biol. Chem. 1987 Sep $15 ; 262(26): 12468-12474$.

35. Palancade $\mathrm{B}$, Bensaude $\mathrm{O}$. Investigating RNA polymerase II carboxyl-terminal domain (CTD) phosphorylation. Eur. J. Biochem. 2003 Oct;270(19):3859-3870.

36. McCracken S, Fong N, Yankulov K, Ballantyne S, Pan G, Greenblatt J, et al. The Cterminal domain of RNA polymerase II couples mRNA processing to transcription. Nature. 1997 Jan 23;385(6614):357-361.

37. Du L, Warren SL. A functional interaction between the carboxy-terminal domain of RNA polymerase II and pre-mRNA splicing. J. Cell Biol. 1997 Jan 13;136(1):5-18.

38. Rickert P, Corden JL, Lees E. Cyclin C/CDK8 and cyclin H/CDK7/p36 are biochemically distinct CTD kinases. Oncogene. 1999 Jan 28;18(4):1093-1102.

39. Hengartner CJ, Myer VE, Liao SM, Wilson CJ, Koh SS, Young RA. Temporal regulation of RNA polymerase II by Srb10 and Kin28 cyclin-dependent kinases. Mol. Cell. 1998 Jul;2(1):43-53.

40. Loyer P, Trembley JH, Katona R, Kidd VJ, Lahti JM. Role of CDK/cyclin complexes in transcription and RNA splicing. Cell. Signal. 2005 Sep;17(9):1033-1051.

41. Furumoto T, Tanaka A, Ito M, Malik S, Hirose Y, Hanaoka F, et al. A kinase subunit of the human mediator complex, CDK8, positively regulates transcriptional activation. Genes Cells. 2007 Jan;12(1):119-132. 
42. Donner AJ, Ebmeier CC, Taatjes DJ, Espinosa JM. CDK8 is a positive regulator of transcriptional elongation within the serum response network. Nat. Struct. Mol. Biol. 2010 Feb;17(2):194-201.

43. Galbraith MD, Donner AJ, Espinosa JM. CDK8: A positive regulator of transcription. Transcr. 2010;1(1):4-12.

44. Akoulitchev S, Chuikov S, Reinberg D. TFIIH is negatively regulated by cdk8-containing mediator complexes. Nature. 2000 Sep 7;407(6800):102-106.

45. Fryer CJ, White JB, Jones KA. Mastermind recruits CycC:CDK8 to phosphorylate the Notch ICD and coordinate activation with turnover. Mol. Cell. 2004 Nov 19;16(4):509-520.

46. Liu ZJ, Tanaka Y, Mine S, Morinobu A, Yagita H, Okumura K, et al. Functional cooperation of cyclin $\mathrm{C}$ and c-Myc in mediating homotypic cell adhesion via very late antigen-4 activation and vascular cell adhesion molecule-1 induction. Blood. 1998 Dec 15;92(12):4700-4711.

47. Takeda K, Saito T, Ochiai H. A novel Dictyostelium Cdk8 is required for aggregation, but is dispensable for growth. Dev. Growth Differ. 2002 Jun;44(3):213-223.

48. Lin H-HS, Khosla M, Huang H-J, Hsu D-W, Michaelis C, Weeks G, et al. A homologue of Cdk8 is required for spore cell differentiation in Dictyostelium. Dev. Biol. $2004 \mathrm{Jul}$ $1 ; 271(1): 49-58$.

49. Greene DM, Hsu D-W, Pears CJ. Control of cyclin C levels during development of Dictyostelium. PLoS ONE. 2010;5(5):e10543.

50. Loncle N, Boube M, Joulia L, Boschiero C, Werner M, Cribbs DL, et al. Distinct roles for Mediator Cdk8 module subunits in Drosophila development. EMBO J. 2007 Feb 21;26(4):1045-1054.

51. Brabazon ED, Bree RT, Carton MW, Grealy M, Byrnes L. Cyclin-dependent kinase 8 is expressed both maternally and zygotically during zebrafish embryo development. Biochim. Biophys. Acta. 2002 Jun 7;1576(1-2):203-208.

52. Westerling T, Kuuluvainen E, Mäkelä TP. Cdk8 is essential for preimplantation mouse development. Mol. Cell. Biol. 2007 Sep;27(17):6177-6182.

53. Katona R, Roby S, Boyd K, Szekely Szucs K, Corroyer S, Hadlaczky G, et al. Cyclin C is essential for normal embryonic development. Nem közölt kézirat.

54. Blazsó P. Cyclin C and the development of mice. Acta Biol Szeged. 2007;51(2):140.

55. Diez-Roux G, Banfi S, Sultan M, Geffers L, Anand S, Rozado D, et al. A high-resolution anatomical atlas of the transcriptome in the mouse embryo. PLoS Biol. 2011;9(1):e1000582.

56. Katona RL, Loyer P, Roby SK, Lahti JM. Two isoforms of the human cyclin C gene are expressed differentially suggesting that they may have distinct functions. Acta. Biol. Hung. 
2007 Mar;58(1):133-137.

57. Oh C, Choi YJ, Kim HG, Lee D-H. Osmosensitive gene expression of taurine transporter and cyclin C in embryonic fibroblast cells. Adv. Exp. Med. Biol. 2006;583:49-57.

58. Polly P, Danielsson C, Schräder M, Carlberg C. Cyclin C is a primary 1alpha,25dihydroxyvitamin D(3) responding gene. J. Cell. Biochem. 2000 Feb;77(1):75-81.

59. Sinkkonen L, Malinen M, Saavalainen K, Väisänen S, Carlberg C. Regulation of the human cyclin $\mathrm{C}$ gene via multiple vitamin D3-responsive regions in its promoter. Nucleic Acids Res. 2005;33(8):2440-2451.

60. Makkonen KM, Malinen M, Ropponen A, Väisänen S, Carlberg C. Cell cycle regulatory effects of retinoic Acid and forskolin are mediated by the cyclin C gene. J. Mol. Biol. 2009 Oct 23;393(2):261-271.

61. de Boer BA, Ruijter JM, Voorbraak FPJM, Moorman AFM. More than a decade of developmental gene expression atlases: where are we now? Nucleic Acids Res. 2009 Dec;37(22):7349-7359.

62. Sambrook J, Fritsch EF, Maniatis T. Molecular cloning: a laboratory manual. 2nd ed. Cold Spring Harbor Laboratory Press; 1989.

63. Nagy A, Gertsenstein M, Vintersten K, Behringer R. Manipulating the Mouse Embryo: A Laboratory Manual, Third Edition. 3rd ed. Cold Spring Harbor Laboratory Press; 2002.

64. Csonka E. De Novo Generation of Satellite DNA-Based Artificial Chromosomes by Induced Large-Scale Amplification. Methods Mol. Biol. 2011;738:111-125.

65. Masek T, Vopalensky V, Suchomelova P, Pospisek M. Denaturing RNA electrophoresis in TAE agarose gels. Anal. Biochem. 2005 Jan 1;336(1):46-50.

66. Bustin SA, Benes V, Garson JA, Hellemans J, Huggett J, Kubista M, et al. The MIQE guidelines: minimum information for publication of quantitative real-time PCR experiments. Clin. Chem. 2009 Apr;55(4):611-622.

67. Lefever S, Vandesompele J, Speleman F, Pattyn F. RTPrimerDB: the portal for real-time PCR primers and probes. Nucleic Acids Res. 2009 Jan;37(Database issue):D942-945.

68. Pfaffl MW. A new mathematical model for relative quantification in real-time RT-PCR. Nucleic Acids Res. 2001 May 1;29(9):e45-e45.

69. Radonić A, Thulke S, Mackay IM, Landt O, Siegert W, Nitsche A. Guideline to reference gene selection for quantitative real-time PCR. Biochem. Biophys. Res. Commun. 2004 Jan 23;313(4):856-862.

70. Laemmli UK. Cleavage of structural proteins during the assembly of the head of bacteriophage T4. Nature. 1970 Aug 15;227(5259):680-685.

71. Walker JM, editor. The protein protocols handbook. 2nd ed. Humana Press; 2002. 
72. Portales-Casamar E, Thongjuea S, Kwon AT, Arenillas D, Zhao X, Valen E, et al. JASPAR 2010: the greatly expanded open-access database of transcription factor binding profiles. Nucleic Acids Res. 2010 Jan;38(Database issue):D105-110.

73. Wasserman WW, Sandelin A. Applied bioinformatics for the identification of regulatory elements. Nat. Rev. Genet. 2004 Apr;5(4):276-287.

74. Fernández-Suárez XM, Schuster MK. Using the Ensembl genome server to browse genomic sequence data. Curr Protoc Bioinformatics. 2007 Jan;Chapter 1:Unit 1.15.

75. Widłak W, Markkula M, Krawczyk Z, Kananen K, Huhtaniemi I. A 252 bp upstream region of the rat spermatocyte-specific hst70 gene is sufficient to promote expression of the hst70CAT hybrid gene in testis and brain of transgenic mice. Biochim. Biophys. Acta. 1995 Nov 7;1264(2):191-200.

76. Scieglińska D, Vydra N, Krawczyk Z, Widłak W. Location of promoter elements necessary and sufficient to direct testis-specific expression of the Hst70/Hsp70.2 gene. Biochem. J. 2004 May 1;379(Pt 3):739-747.

77. Hsu SY, Lai RJ, Nanuel D, Hsueh AJ. Different 5'-flanking regions of the inhibin-alpha gene target transgenes to the gonad and adrenal in an age-dependent manner in transgenic mice. Endocrinology. 1995 Dec;136(12):5577-5586.

78. Cheng CK, Cheung CH, Lee WM. Mouse testin: complementary DNA cloning, genomic organization, and characterization of its proximal promoter region. Biol. Reprod. 2003 Apr;68(4):1376-1386.

79. Reddi PP, Urekar CJ, Abhyankar MM, Ranpura SA. Role of an insulator in testis-specific gene transcription. Ann. N. Y. Acad. Sci. 2007 Dec;1120:95-103.

80. Yamashita A, Goto N, Nishiguchi S, Shimada K, Yamanishi H, Yasunaga T. Computational search for over-represented 8-mers within the 5'-regulatory regions of 634 mouse testisspecific genes. Gene. 2008 Dec 31;427(1-2):93-98. 


\section{Magyar nyelvű összefoglaló}

A ciklin $\mathrm{C}(\mathrm{CCNC})$ az állatvilágban egy rendkívüli mértékü szerkezeti konzerváltságot mutató ciklin, amelyet nagyfokú pleiotrópia jellemez. A sejtciklus, a génátírás és a sejt-sejt kapcsolat szabályozásában vesz részt. Ciklin-függő szerin-treonin kinázokhoz kötődve, azokat aktiválva heterodimer enzimkomplexeket képez. Sejtbiológiai müködését az érintett biokémiai útvonalakban való részvételén, illetve fehérjepartnerein keresztül lehet leginkább jellemezni. A sejtciklus szabályozásban eddig két ismert molekuláris mechanizmussal vesz részt. A ciklin $\mathrm{C}$ kötődik a CDK2 enzimhez, amellyel együttesen az LSF (late Simian vacuolating virus 40 factor) transzkripciós faktor 309. szerinjének foszforilációjával meggátolja ezt a fehérjét abban, hogy a G1 fázisban indukáljon jellemzően S-fázis géneket. A CCNC/CDK3 enzimkomplex a pRb (Retinoblastoma) 807/811-es szerinjeinek foszforilálásán keresztül az E2F (adenovirus E2 promoter factor) pRb-ről történő leválasztásával, azaz aktiválásával indirekt módon hozzájárul a sejtek S fázisba léptetéséhez. Ennek eredményeképp úgy változik meg a sejt génexpressziós profilja, hogy a sejtciklus továbbhaladhasson a G0/G1/S átmenetben. A ciklin $\mathrm{C}$ a génátírás egyes lépéseit is serkentheti, illetve gátolhatja. Ezeket a hatásait leginkább a CDK8 kináz partnerével együtt többnyire egy RNS átírást szabályozó ún. Mediator komplexnek a CDK alegységében fejti ki. Ismert, hogy a CCNC/CDK8 enzim foszforilálja az RNS polimeráz II CTD (karboxi terminális domén) régiójában a Ser-2 és Ser-5 aminosavakat, a TFIIH (általános transzkripciós faktor IIH) ciklin H alegységének 5-ös és 304-es szerinjeit valamint a Notch ICD komponensét is képes hiperfoszforilálni. Ezeken kívül a ciklin C kináz partnertől független módon, a c-Myc fehérjével együttműködve elősegíti a sejt-sejt kapcsolatok kialakítását, amelynek hátterében a VCAM-1 (vascular cell adhesion molecule 1) és a VLA-4 (very late antigen 4) integrinek egymástól független aktivációja áll. A génátírás, a sejtciklus valamint a sejtadhézió szabályozása alapvető részeit képzik az egyedfejlődési programoknak. Egyre több 
direkt és indirekt bizonyíték lát napvilágot, amelyek mind jobban hangsúlyozzák a CCNC jelentőségét az eukarióta szervezetek egyedfejlődésében is. A sejtes nyálkapenész (Dictyostelium discoideum) korai fejlődési, sejtsors meghatározási folyamatainak időzítésében vesz részt. Drosophila melanogasterben a korai bábállapotból történő továbbhaladásnál létfontosságú a CCNC jelenléte, illetve házi egérben (Mus musculus) is az embrionális fejlődés kezdeti szakaszában, feltehetően sejtsorsok meghatározásában játszik közre.

A ciklin C szöveti/szervi szinten betöltött szerepéröl még keveset tudunk. Ahhoz, hogy részleteiben is feltárhassuk a ciklin C fehérjének ezen funkcióit, szükség van arra, hogy az időés térbeli kifejeződését követni tudjuk. Ezen túlmenően azon tényezők azonosítása is szükséges, amelyek a CCNC gén expressziójára hatást gyakorolnak. Emberi sejtkultúrákon, in vitro kísérletekben bemutatták, hogy a $\mathrm{D}_{3}$ vitamin, transz retinsav, illetve a cAMP (ciklikus adenozin monofoszfát) a megfelelő sejtmagi elemeiken keresztül a CCNC promóteréhez kötődve befolyásolják a gén átírását. Azt is tudjuk, hogy ezek az elemek jobbára a ciklin C promóter első 3 kilobázisnyi szakaszán keresztül hatnak, de azt nem, hogy ez a DNS fragment elegendö-e emlősökben a ciklin C kifejeződésének teljes, élettani szabályozásához. Nem ismert az sem, hogy milyen más elemek játszhatnak még közre. Ahhoz, hogy ezen kérdésekre válaszokat kapjunk, az egér CCNC transzlációs startpontjával 5' irányban szomszédos, különböző hosszúságú DNS szakaszokat építettünk össze a hrGFP jelzőgénnel. Ezután ezen jelzőgén konstrukciók kifejeződését vizsgáltuk meg in vitro emlős sejtekben, illetve in vivo transzgenikus egérmodellben.

Munkánk során bebizonyítottuk, hogy az egér ciklin C promóterének első 3,4 és 10,4 kilobázis méretü szakaszai az 5'UTR 1-173 nukleotidjaival képesek emlős sejtekben génkifejeződést kiváltani. Ezzel szemben a promóter első 58 bázispáros darabjának az 5'UTR-rel együttes hiánya jelentősen, azaz az észlelési küszöb alá csökkenti az expressziót. Leginkább a proximális 
promóterszakasz (és nem az 5'UTR) hiánya állhat ennek a jelenségnek a hátterében, mert feltételezésünk szerint az RNS polimeráz II kötődhet le ebben a régióban, bár ezt kísérletesen nem vizsgáltuk. Eredeti törekvésünk arra irányult, hogy egérmodellben egy jelzőgénnel egyszerüen tudjuk követni a ciklin $\mathrm{C}$ tér- és időbeli génkifejeződését. Ennek érdekében az előzetesen sejtkultúrákban is kipróbált 3,4 kb hosszúságú ciklin C promóterdarabot és 5'UTR-t egyszerre tartalmazó jelzőgén konstrukcióval, azaz P3CG-vel négy különböző homozigóta transzgenikus egérvonalat állítottunk elő. A transzgenikus egerek vizsgálata során kiderült, hogy az eredetileg kitüzött célra nem alkalmasak. A jelzőgén kifejeződése nagyon gyenge és hírvivő RNS-ének átírása is következetesen leginkább csak a herére korlátozódik. Ezzel szemben a ciklin C1 és C2 izoformák RNS expressziója kimutatható az összes általunk vizsgált szervdarabban, csakúgy, mint a felnőtt emberek szervmintáiban is. Mindezekből az is következik, hogy a ciklin C térbeli expressziós szabályozásában az izolált promóterszakaszon kívül más komponensek is részt vesznek. Ezen túlmenően kimutattuk, hogy az egér CCNC promóterének első 3,4 kilobázisnyi szekvenciája tartalmaz három CRE motívumot. Az emberi ciklin $\mathrm{C}$ gén promóterének első 3 kilobázisnyi szakaszán is azonosítottak négy müködő CRE-t. Mivel korábban a here specifitást mutató promóterekröl leírták azt is, hogy a többi promóterhez képest több CRE helyet tartalmaznak, így feltételezzük, hogy a herében a CCNC expressziójának fenntartásához is a CRE kötő transzkripciós faktorok jelentősen hozzájárulnak. Összességében, a bemutatott eredmények felvetik a ciklin $\mathrm{C}$ herére jellemző egyedi, eddig még ismeretlen szerepét. 


\section{English summary of the Ph. D. thesis}

Cyclin $\mathrm{C}(\mathrm{CCNC})$ is an exceptionally conserved cyclin among animals which is characterized by strong pleiotropy. It takes part in the regulation of cell cycle, messenger RNA transcription and cell adhesion. It activates serine-threonine cyclin-dependent kinases (CDKs) by binding to them and together they form heterodimeric enzyme complexes. Cell biology functions of CCNC can be described mainly by its protein partners and its roles in biochemical pathways. Two mechanisms are known by which it regulates the cell cycle. Cyclin $\mathrm{C}$ binds to CDK2 and together they phosphorylate serine 309 residue of LSF (late Simian vacuolating virus 40 factor) transcription factor which prevents this protein from inducing typical S-phase genes in G1. $\mathrm{CCNC/CDK3}$ enzyme complex contributes to the transition to S-phase by phosphorylating $\mathrm{pRb}$ (Retinoblastoma) at 807/811 serines. This way it activates E2F (adenovirus E2 promoter factor) by detaching from $\mathrm{pRb}$. This results in the gene expression profile alteration that eventually makes the cells pass through G0/G1/S transition. Cyclin C can either up- or downregulate gene transcription as well. These regulatory effects are elicited together with CDK8 kinase partner in the CDK subunit of the RNA transcription regulator Mediator complex. CCNC/CDK8 is proven to phosphorylate Ser-2 and Ser-5 amino acids of RNA polymerase II's CTD (carboxy terminal domain), Ser-5 and Ser-304 of TFIIH's (general transcription factor IIH) cyclin H subunit and the ICD component of Notch. Moreover, it cooperates functionally with c-Myc in cell adhesion via a kinase independent way. In the background, parallel activation of VCAM-1 (vascular cell adhesion molecule 1) and VLA-4 (very late antigen 4) integrins is found. Regulation of gene transcription, cell cycle and cell adhesion are core events of developmental programs. Direct and indirect evidence are also accumulating that emphasize the important role of CCNC in the development of eukaryotic organisms. It mediates the timing of slime mold's (Dictyostelium discoideum) early cell fate determination. It is an essential regulator in progression from the 
early pupal stages of Drosophila melanogaster and in house mouse (Mus musculus) it is also found to be indispensable during the initial stages of embryonic development. In addition to fruitfly in case of mice it may also play a role in cell fate decision.

There is little known about the functions of cyclin $\mathrm{C}$ at the tissue/organ level. Tracking of spatiotemporal gene expression is needed in order to reveal these functions. Furthermore, factors that influence $\mathrm{CCNC}$ expression must also be identified. It is demonstrated in vitro on human cell cultures that vitamin $\mathrm{D}_{3}$, ATRA (all-trans retinoic acid) and cAMP (cyclic adenosine monophosphate) regulate the gene's transcription thorough their corresponding nuclear elements by binding to the promoter of cyclin C. These elements are known to have their effect mostly through the first 3 kilobase of CCNC promoter but no evidence exists whether this DNS fragment is sufficient for the full physiological regulation of cyclin C's expression. There is no information on what other elements can affect this process. In order to get answers to these questions we ligated DNA fragments of different lengths from the upstream flanking region of CCNC gene to hrGFP reporter gene. The resulting reporter constructs were used to assess their expression in vitro in mammalian cells and in vivo in transgenic mice.

We have proven that first 3.4 and 10.4 kilobases of cyclin C promoter plus 173 nucleotides of the 5'UTR are capable of eliciting expression in mammalian cells. In contrast, deletion of the first 58 base pairs and 5'UTR significantly reduces expression. We think that the loss of the first 58 nucleotides of the CCNC promoter alone (and not the loss of 5'UTR) causes this phenomenon since this region may contain the binding site of RNA polymerase II, however this has not been analyzed. Our original aim was to track the spatiotemporal expression characteristics of cyclin C. For this the already tested $3.6-\mathrm{kb}$ promoter fragment - 5'UTR - hrGFP construct was used to establish four different, homozygous transgenic mouse lines. During the analyses of transgenic mice, they were turned out to be inappropriate for our original plans. Reporter transgene was 
found to express very weakly and its messenger RNA transcription is limited mainly and consistently to testes. However, similarly to human samples RNAs of cyclin C1 and C2 isoforms are detectable in all examined organ specimens. We also conclude that other components are needed besides the isolated CCNC promoter and 5'UTR fragment for the proper regulation of CCNC's spatial expression. In addition, we found three CRE motifs in the 3.4-kb sequence of the mouse cyclin $\mathrm{C}$ promoter. The first 3 kilobases of human cyclin $\mathrm{C}$ promoter also contains four functional CRE sites. Since testis-specific promoters were proven previously to contain more CRE motifs than other promoters, we assume that CRE binding factors significantly contribute to the maintenance of testicular expression of cyclin $\mathrm{C}$ as well. In summary, the demonstrated results suggest a unique, but still unknown testis-specific role of cyclin $\mathrm{C}$. 